\title{
ANTECEDENTES Y ORÍGENES DE LAS PRIMERAS EXPERIENCIAS DE PERONIZACIÓN EN LA UBA. 1966 - 1970
}

\author{
Background and origins of the first experiences of peronization in the UBA \\ $1966-1970$
}

\begin{abstract}
Nicolás Dip*
\section{Resumen}

En este artículo reconstruimos las primeras experiencias de peronización de estudiantes, docentes e intelectuales porteños tras el golpe de Estado de 1966. Luego de una introducción referida a cómo algunos protagonistas de la época interpretaron la intervención universitaria decretada por el régimen militar, repasamos las agrupaciones estudiantiles que tramitaron su pasaje al peronismo con posterioridad a ese hecho, pero prestando atención a la trayectoria previa de sus principales dirigentes y militantes. Después, analizamos cómo entendían al peronismo y el papel clave que jugó la CGT de los Argentinos en este tema. Finalmente, indagamos la trayectoria de los integrantes de las Cátedras Nacionales de la Facultad de Filosofía y Letras y su influencia en la politización de universitarios porteños. A partir de ese orden temático, los primeros apartados del artículo realizan una reconstrucción historiográfica de las experiencias señaladas y el último retoma dichos aportes para problematizar la manera de enfocar la peronización en los estudios recientes.
\end{abstract}

$<$ Peronización $><$ Universidad $><$ Politización $><$ Nueva izquierda $>$

\begin{abstract}
In this article I intend to reconstruct the first experiences of peronization on students, teachers, and intellectuals of Buenos Aires, after the 1966 coup d'État. After an introduction on the manner that some contemporary protagonists interpreted the university intervention decreed by the military regime, I will focus on the student groups that changed their affiliations towards Peronism after that fact. In this regard, I will examine the previous career of their main leaders and militants. Secondly, I will inquire on the manner in which they understood Peronism and the key role played by the CGT de los Argentinos in this matter. Finally, I will analyze the career of the members of the National Chairs of the Faculty of Philosophy and Letters, and their influence on the politicization of university students from Buenos Aires. Within this thematic order, the first sections of the article present a historiographical reconstruction of the aforementioned experiences, while the last section seeks to problematize the manner in which the subject of peronization is approached in recent studies, on the basis of the experiences mentioned.
\end{abstract}

$<$ Peronization $><$ University $><$ Politization $><$ New Left $>$

Recibido: 26/05/2017 // Aceptado: 14/07/2017

* Licenciado en Sociología y Doctor en Historia por la Facultad de Humanidades y Ciencias de la Educación de la Universidad Nacional de La Plata. Becario Postdoctoral del Consejo Nacional de Investigaciones Científicas y Técnicas (CONICET). Jefe de Trabajos Prácticos en Teoría del Estado de la Facultad de Trabajo Social de la Universidad Nacional de La Plata. nicolasdip88@gmail.com. 
Dip. Antecedentes y orígenes de las primeras experiencias de peronización en la UBA. 1966 - 1970.

\section{La noche de los bastones largos}

El 28 de junio de 1966 un destacamento de policías de la guardia de infantería expulsó al presidente Arturo Illia de la Casa Rosada. La segunda experiencia de gobierno civil emprendida desde el derrocamiento del peronismo llegaba a su fin y los militares intervenían nuevamente en la política Argentina. A nadie le llamó la atención que al día siguiente asumiera la presidencia el general Juan Carlos Onganía. La destitución de la administración de la Unión Cívica Radical del Pueblo venía discutiéndose públicamente desde hacía tiempo y contó con un respaldo social, político y mediático importante. El poderoso líder de la Unión Obrera Metalúrgica (UOM), Augusto Timoteo Vandor, acudió a la asunción de Onganía e incluso el gran excluido de la política argentina brindó ese mismo día una entrevista exclusiva a Primera Plana donde caracterizaba a los artífices de la destitución de Illia como un "movimiento simpático" que cerraba una etapa de "verdadera corrupción". Aunque Juan Domingo Perón le aclaraba al periodista Tomás Eloy Martínez que eso no significaba entregarle un "cheque en blanco", ya que esperaba que el nuevo presidente aprovechara la "última oportunidad" que tenía la Argentina para evitar una "guerra civil" y retornar en un corto período a un régimen de elecciones libres sin proscripciones ${ }^{1}$.

En este contexto expectante, la UBA fue la única institución pública en poner reparos contra el golpe. Mediante una declaración, el rector humanista Hilario Fernández Long junto a la mayoría del Consejo Superior calificó al 28 de junio como un "día aciago" y llamó a la defensa de la autonomía universitaria ${ }^{2}$. La reacción fue inmediata, a un mes de esas declaraciones el régimen militar intervino las universidades nacionales mediante el decreto-ley 16.912 y desalojó violentamente a las facultades porteñas que habían sido tomadas en señal de protesta. La de Ciencias Exactas fue la que contó con el mayor número de heridos y detenidos. Sergio Morero, el cronista de noticias universitarias de Primera Plana, nominó a los sucesos como "La noche de los bastones largos" porque en ese momento le habían hecho recordar a "La noche de los cuchillos largos", la serie de purgas y asesinatos políticos que llevó adelante el Partido Nacionalsocialista Obrero Alemán en 1934 (1996: 5). Desde ya que hubo una distancia enorme entre los dos acontecimientos. Todos los estudiantes y docentes porteños encarcelados el 29 de julio recuperaron su libertad al poco tiempo del operativo policial. Pero retomamos esta nominación que pasó a la historia para dar cuenta de una característica que tuvo la intervención en la UBA: contó con una gran repercusión pública y desató una inmensa cantidad de opiniones e interpretaciones de lo sucedido en distintos actores del campo político, social y cultural argentino.

Al principio, los que intentaron hacer más visibles sus pareces fueron los sectores directamente afectados con la nueva situación. Un mes después de la normativa de Onganía que suprimió la autonomía y el gobierno tripartito, el reconocido reformista Risieri Frondizi, quien había sido rector de la UBA entre 1957 y 1962, calificó

\footnotetext{
1 "Perón: tres horas con Primera Plana", en Primera Plana, Edición Especial, 30 de junio 1966.

"Declaración de la Universidad de Buenos Aires", 28 de junio 1966. Se puede consultar el documento en Baschetti (2016: 144).
} 
públicamente a esos hechos como "la crisis universitaria más grave desde la época de Rosas". A su entender, "jamás habían renunciado tantos profesores” y encima habían "destruido con torpeza" la obra de "modernización académica" que ellos mismos habían iniciado a fines de los cincuenta ${ }^{3}$. En la misma semana de septiembre en que Frondizi brindó sus declaraciones a Primera Plana, la Federación Universitaria Argentina (FUA) convocó a una movilización nacional en Córdoba para amplificar las protestas. La manifestación se llevó a cabo el día 7, pero fue reprimida y produjo la muerte del militante estudiantil Santiago Pampillón. Desde el mes de octubre la oposición universitaria comenzó su declive y en abril del año siguiente Onganía finalmente decretó una nueva ley universitaria (17.245) que prohibía cualquier tipo de actividad política en las aulas.

Entre fines de los sesenta y principios de los setenta, se reactivó la oposición universitaria en medio de las grandes protestas populares contra la dictadura y la proliferación de actores políticos, sociales y culturales que reclamaban salidas revolucionarias. En ese marco, comenzaron a hacerse visibles un conjunto de interpretaciones sobre la intervención de 1966 que resaltaban aspectos positivos de la misma, a pesar de provenir de opositores a Onganía. Un año antes del Cordobazo, el Grupo Cine Liberación proyectó La Hora de los Hornos en Italia, un documental político con fuertes críticas al régimen militar que fue premiado internacionalmente y circuló ampliamente en el país de manera clandestina. En el film, Julio Bárbaro, el presidente de La Liga Humanista de Buenos Aires, sostenía que el golpe de Estado había terminado "aportando al proceso revolucionario" porque obligó a los universitarios a salir de su "isla" y a encontrarse con el peronismo en la proscripción ${ }^{4}$. Unos años después, esta misma idea fue repetida y mejor explicitada por Alcira Argumedo, una docente que había sido militante reformista y en ese entonces era parte de las Cátedras Nacionales de la Facultad de Filosofía y Letras. A su entender, la intervención de Onganía hizo más por una "politización real" de los universitarios que "50 años de Reforma", debido a que desde 1966 se había acabado su "isla democrática" y habían comenzado a confluir con el movimiento peronista ${ }^{5}$.

Estas últimas interpretaciones llamaban la atención porque eran realizadas por una docente y un estudiante que provenían del reformismo y el humanismo, dos sectores que no sólo habían sido activos militantes del golpe de Estado contra Perón en 1955, sino que incluso sus principales referentes en la UBA, como Frondizi y Fernández Long, habían rechazado fuertemente la intervención universitaria en 1966. Pero más allá de las valoraciones que realizaban los protagonistas de la época y de otro sinfín de voces que pueden encontrarse en aquellos años, tomamos como punto de partida estos relatos para preguntarnos por la peronización de estudiantes, docentes e intelectuales porteños en la etapa que siguió a la llegada de Onganía al poder ¿Qué magnitud tuvo ese pasaje al peronismo? ¿Fue un proceso ampliamente difundido o estuvo acatado a ciertos sectores particulares? ¿Comenzó a partir de 1966 como señalan algunos relatos de época o puede

3 "Declaraciones del Dr. Risieri Frondizi", en Primera Plana, No 193, 6-12 de septiembre 1966.

Solanas, F., y Getino, O., La Hora de los Hornos, Grupo Cine Liberación, 1968.

5 Argumedo, A., "Cátedras Nacionales: una experiencia peronista en la Universidad", en Envido, $\mathrm{N}^{\circ} 3$, abril 1971, p. 56. 
Dip. Antecedentes y orígenes de las primeras experiencias de peronización en la UBA. 1966 - 1970.

rastrearse antecedentes en años anteriores? ¿Existieron organizaciones estudiantiles o grupos de docentes e intelectuales que canalizaron esa experiencia? ¿De qué espacios procedían esos estudiantes, docentes e intelectuales peronizados? ¿Cómo entendían al peronismo y cuáles eran sus posicionamientos políticos? ¿Con qué actores concretos del movimiento peronista tenían relaciones?

\section{Nuevos estudiantes peronistas en la UBA}

Durante el primer peronismo habían naufragado los intentos de generar una organización política del estudiantado que sea capaz de disputar el histórico predominio reformista de la FUA y la FUBA. A fines de los cuarenta, Antonio Cafiero y otros alumnos enrolados en el nacionalismo católico fracasaron en su plan de asentar la Federación General de Estudiantes Peronistas. La misma suerte corrió, unos años después, la creación por impulso oficial de la Confederación General Universitaria (CGU). Esta organización surgida a fines de noviembre de 1950 se definía a sí misma como una entidad juvenil, sindical, federal, asistencial, cristiana y revolucionaria. En su órgano de prensa Actitud. Periódico de la juventud argentina mostraba una fuerte impronta anticomunista y católica. La CGU desarrolló principalmente actividades gremiales y participó en los órganos de gobierno de las casas de estudio, por ser la única entidad reconocida al amparo de la ley universitaria de 1954. Sin embargo, y a pesar del respaldo oficial, tuvo una pobre representatividad en la UBA donde no logró hacer mella a la hegemonía y a la militancia opositora del movimiento reformista. El derrocamiento del peronismo gobernante terminó sellando su extinción ${ }^{6}$.

En la primera mitad de los sesenta, tampoco corrió mejor suerte el peronismo en la UBA, aunque cambió su tonalidad política en el marco de los grupos juveniles que aparecieron al poco tiempo de la proscripción. El más conocido de ellos fue el de "Corrientes y Esmeralda", integrado por Envar El Kadri, Jorge Rulli, Susana Valle, Gustavo Rearte, Héctor Spina, entre otros. Estos distintos núcleos encararon un lento proceso de convergencia que derivó en la creación de la Mesa Ejecutiva de la Juventud Peronista en 1959 (Acha, 2011: 25)7. Bajo este antecedente, surgieron en algunas facultades grupos peronistas referenciados en la sigla ANDE: Agrupación Nacional de Estudiantes. Con la finalidad de coordinarlas, nació la Juventud Universitaria Peronista (JUP) en 1962. Esta experiencia de enlace fue efímera, pero llegó a publicar dos números de la revista 4161. El primero fechado en octubre de 1963 y el segundo en junio de 1964. La publicación tenía notas dedicadas a la política y a la universidad ${ }^{8}$. En

${ }^{6}$ La CGU tuvo escasa representatividad en las grandes universidades de Buenos Aires y La Plata, aunque la exigua bibliografía sobre el tema destaca una presencia más aceptable en el interior del país. Véase Acha (2011: 77-84) y Panella (2013).

7 La investigación de Acha discute que la primera JP haya surgido con posterioridad a 1955. En verdad, su origen hay que rastrearlo durante el decenio peronista anterior.

8 Hugo Chumbita tuvo un papel destacado en la elaboración de la revista. De acuerdo a su testimonio, fue el secretario de prensa de la JUP y el encargado de 4161. A su vez, en ANDE y/o JUP participaron Oscar Balestieri, Mario Kestelboim y Lelio Mármola. Entrevista a Hugo Chumbita, C.A.B.A., 05/01/2016; Entrevista a Oscar Balestieri, C.A.B.A., 02/12/2015; Entrevista a Mario Kestelboim, C.A.B.A., 
las primeras, la JUP se presentaba a sí misma como una "generación joven" originada en la "lucha revolucionaria" que siguió a septiembre de 1955. Esta autoapreciación era común en grupos de JP que pretendían diferenciarse de una supuesta dirigencia "traidora" y "negociadora" que había claudicado frente al derrocamiento del peronismo (Bozza, 2014: 75-76). Desde esta perspectiva general, la JUP se identificaba con el sector del sindicalismo combativo agrupado detrás de Andrés Framini, el dirigente textil que había sido electo gobernador de la provincia de Buenos Aires en las elecciones de 1962, las cuales finalmente fueron anuladas y precipitaron la destitución de Arturo Frondizi de la presidencia de la Nación. A través de la figura de Framini, 4161 exaltaba el programa de Huerta Grande de las 62 organizaciones como el único capaz de garantizar una "doctrina revolucionaria" en el peronismo".

Las notas referidas a la universidad en 4161 seguían un razonamiento similar a las de carácter político. La JUP se presentaba como una nueva experiencia militante diferente a la antigua CGU, a la que consideraba una estructura caduca que no había hallado eco en las universidades de Buenos Aires y La Plata, y que incluso se había desgranado por "errores y abusos" de los "eternos aprovechadores que la pusieron al servicio de intereses mezquinos" $"$. A esta lectura sobre el pasado, la JUP sumaba una fuerte crítica al panorama político de la UBA de ese entonces. A su entender, luego de la disputa "laica o libre", los "humanistas católicos" y los "reformistas laicos" terminaron estableciendo una alianza que mantenía los pilares de la universidad instaurada con posterioridad a 1955. El traspaso del rectorado de Risieri Frondizi a Julio Olivera en 1962, no habría modificado en nada su actitud de "isla democrática" frente a la proscripción del peronismo y su incursión en políticas "limitacionistas" y "cientificistas"11. Frente a esta situación, la JUP consideraba que su tarea era impulsar la "nacionalización mental" de los estudiantes para ligarlos a la "lucha concreta" de los trabajadores, mediante su presencia en el quehacer extrauniversitario y universitario. Aunque en este último punto, la práctica de la propia organización parecía dar a entender que por actividad política en la universidad no concebían más que denunciar, abstenerse o votar en blanco en las elecciones estudiantiles, organizar conferencias y trastocar la estabilidad de las casas de estudio con "tomas" y "actos relámpagos". Sugestivo de esto era que sólo participaron en una oportunidad en las elecciones de la Facultad Derecho y las dos ocupaciones que realizaron del rectorado de la calle Florida: una el 27 de mayo de 1964

12/11/2015; Entrevista a Lelio Mármola realizada por Aritz Recalde, C.A.B.A., 23/06/2006.

9 "Huerta Grande 10 objetivos revolucionarios", en 4161, $\mathrm{N}^{\circ} 1$, octubre 1963. En ese tiempo, el sindicalismo combativo peronista produjo dos programas importantes: el de la Falda en 1957 y el de Huerta Grande en 1962. Ambos tenían tintes anticapitalistas y antiimperialistas. Entre sus medidas, figuraban la nacionalización de sectores claves de la economía y el control obrero de la producción.

10 "J.U.P. breve historia", en 4161, N 1, octubre 1963.

11 "Desarrollismo, humanismo y reforma en el gobierno universitario", en $4161, \mathrm{~N}^{\circ} 2$, junio 1964. Con la idea de "isla democrática" hacían referencia a la existencia de elecciones libres en la universidad y no en el resto del país. Por "limitacionismo" entendían una política universitaria tendiente a recortar el presupuesto e impedir con distintas trabas el ingreso de los sectores populares a las casas de estudio. Cuando hablaban de "cientificismo", hacían alusión a un tipo de desarrollo científico desligado del compromiso político y subordinado a los subsidios de organismos y fundaciones estadounidenses. 
Dip. Antecedentes y orígenes de las primeras experiencias de peronización en la UBA. 1966 - 1970.

en el marco del Plan de Lucha de la CGT y la otra el 16 de septiembre de ese mismo año, en repudio de un nuevo aniversario de la "Revolución Libertadora" ${ }^{2}$. Más que una militancia específica en el ámbito estudiantil, el norte de la JUP parecía ser el de captar universitarios para insertarlos en las actividades del sindicalismo y las organizaciones políticas del peronismo proscripto.

Hacia mediados de los sesenta, la JUP corrió el mismo destino que la antigua CGU. Había hallado poco eco entre el alumnado y terminó desarticulándose. En respuesta a esta situación, los ANDE y lo que quedaba de la JUP formaron en 1966 la Federación de Agrupaciones Nacionales de Estudiantes Peronistas (FANDEP) ${ }^{13}$. Aunque el cambio de siglas y la creación de la nueva entidad tampoco trajeron una modificación sustancial en su peso e influencia en el ámbito porteño. De todas maneras, 1966 no fue un año más en la historia de la universidad argentina y, en cierta medida, trajo un antes y un después en muchos aspectos. Uno de estos cambios fue la aparición de nuevas agrupaciones estudiantiles que progresivamente se identificaron con el peronismo. En el contexto de la intervención de Onganía, ellas permitieron robustecer la presencia política de dicho movimiento en las casas de estudio y nutrirlo de un conjunto de militantes que provenían, en buena medida, de esos sectores humanistas y reformistas que la revista 4161 señalaba como los responsables de la indiferencia universitaria frente a la proscripción del peronismo. En los siguientes subapartados, reconstruimos el itinerario de esas organizaciones, haciendo hincapié en la trayectoria de sus principales dirigentes. Más adelante, nos concentramos en sus posicionamientos políticos durante la segunda mitad de los sesenta.

\section{El Frente Estudiantil Nacional}

A sólo un año del golpe de Onganía surgió el Frente Estudiantil Nacional (FEN), a raíz de una articulación entre agrupaciones de Buenos Aires, Rosario y Córdoba que luego se extendió rápidamente a Mendoza, Tucumán y Mar del Plata. Aunque la columna vertebral de la organización y su centro fundacional estaban vinculados a la Facultad de Filosofía y Letras de la UBA, especialmente a la joven carrera de Sociología (Reta, 2010: 7; Grabois, 2014: 15). De ese ámbito provenía Roberto Grabois, el principal referente e impulsor de la agrupación. "Pajarito" había empezado a militar tempranamente en las filas del Partido Socialista (PS). Luego de su ruptura en 1958, quedó vinculado al sector del PS Argentino (PSA) que se distanció de la política más antiperonista del ghioldismo, agrupado en el PS Democrático ${ }^{14}$. En 1961, Grabois participó activamente en la victoria electoral de Alfredo Palacios como senador por Capital Federal; proceso que contó con el respaldo del Partido Comunista (PC) y estuvo

12 "Ocupación de las universidades por las Juventudes Universitarias Peronistas", en 4161, N² 2, junio 1964. También pueden consultarse documentos sobre las "tomas" en Baschetti (2016: 133).

${ }^{13}$ Una reseña de los orígenes de FANDEP, puede consultarse en: "Herederos de la práctica popular", en Primera Plana, $\mathrm{N}^{\circ}$ 488, 6 de junio 1972.

${ }^{14}$ En el PSA convergieron la juventud socialista junto a dirigentes como Alfredo Palacios, Alicia Moreau de Justo y Carlos Sánchez Viamonte. Para un análisis de las distintas rupturas que sufrió el PS en los sesenta, véase Tortti (2009). 
tenido de una fuerte tónica pro cubana ${ }^{15}$. A esto se sumaban los contactos previos de algunos militantes del PSA con sindicalistas del peronismo combativo, que incluso se remontaban a la toma del Frigorífico Lisandro de la Torre de 1959 (Grabois, 2014: 65 68). Luego del triunfo de Palacios, los comunistas y socialistas más entusiastas con la Revolución Cubana que participaban en la revista Che, hablaban de la necesidad de formar un frente de liberación nacional con la presencia de esas tres fuerzas políticas ${ }^{16}$. Si bien Grabois no formó parte de ese proyecto editorial y de las siguientes fracturas del socialismo que dieron origen al PS Argentino de Vanguardia (PSAV), experimentó todas estas discusiones ${ }^{17}$.

En 1963, luego de un breve paso por la Facultad de Derecho, Grabois recaló en la carrera de Sociología y desde ese ámbito se incorporó a la Lista de Izquierda Mayoritaria (LIM) que lideraba Daniel Hopen, un estudiante avanzado enrolado en las filas de Palabra Obrera (PO); organización trotskista que en ese momento encabezaba Nahuel Moreno y predicaba el "entrismo" en el peronismo ${ }^{18}$. El LIM tenía contactos políticos con la Tendencia Antiimperialista Universitaria (TAU), una entidad estudiantil que se referenciaba con el Movimiento de Izquierda Revolucionaria Argentina (MIRA), otra organización trotskista cuyo referente en la UBA era el estudiante de Derecho Héctor Poggiese $^{19}$. En marzo de 1964, el LIM y el TAU impulsaron un acto en Filosofía y Letras donde recordaron a los fusilados de José León Suárez y homenajearon a los abatidos en la fallida incursión del Ejército Guerrillero del Pueblo (EGP) en la salva salteña (Califa, 2014: 256-257). Junto a Jorge Masetti, habían perdido la vida cuatro estudiantes de esa facultad, entre los cuales estaba Marcos Slajter, uno de los primeros graduados de Sociología que militaba en el Movimiento de Liberación Nacional (MLN) de los hermanos Viñas ${ }^{20}$.

${ }^{15}$ El ala izquierda del PSA, vinculada a dirigentes juveniles como Alexis Latendorf y David Tieffenberg, jugó un papel clave en el acuerdo con el PC y en la búsqueda de apoyo de sectores del peronismo combativo, entre los cuales estaban Jorque Di Pasquale y Sebastián Borro (Tortti, 2009: 164-165).

${ }^{16}$ En 1961 la revista Che era un proyecto compartido entre la izquierda del PSA y el PC, aunque ello no fuera explicitado en sus páginas (Tortti, 2013).

${ }^{17}$ En este punto, es importante tener en cuenta que Tieffemberg, uno de los principales impulsores del PSAV, era primo hermano de la madre de Grabois, con lo cual ambos tuvieron contactos desde muy temprano. El PSAV profundizó la línea política que apuntaba a la formación de un frente de liberación nacional basado en la unidad de la izquierda y el peronismo combativo.

${ }^{18}$ Dentro del trotskismo argentino, PO se caracterizó por su fuerte ligazón con el peronismo y por su política "entrista", la cual consistía en insertarse en los movimientos de masas con el objetivo de "ganar" grupos y orientarlos hacia el partido revolucionario. Hopen estaba relacionado al sector de PO dirigido por Ángel Bengochea, quien a principios de los sesenta viajó a Cuba y entabló contactos políticos con el "Che" Guevara (Tarcus, 2007: 306-307).

${ }^{19}$ El MIRA era encabezado por Ramón Horacio Torres Molina. Surgió en 1961 a raíz de una ruptura del MIR Praxis de Silvio Frondizi; alegando, entre otras cosas, la necesidad de una ideología revolucionaria y nacionalista que comprendiera mejor al peronismo. Cuando el MIRA se disolvió en 1965, varios de sus integrantes pasaron al peronismo y tuvieron influencia en la formación de la Federación Universitaria de la Revolución Nacional (FURN), una de las primeras agrupaciones universitarias que se definió como peronista. Bajo la influencia de John William Cooke, su primera conducción combinaba adhesión al peronismo y a la lucha armada (Tarcus, 2007: 225-227; Tortti, 2009: 368).

${ }^{20}$ Al EGP estuvieron vinculados grupos disidentes del PC como el de José Aricó, algunos activistas del 
Un año después de estos sucesos, Grabois fue candidato a presidente del Centro de Estudiantes de Filosofía y Letras (CEFYL) por la lista del Frente Antiimperialista Universitario (FAU), el cual había surgido de la alianza entre el LIM y el TAU. La elección la terminó perdiendo frente a Acción Reformista de Filosofía y Letras (ARFYL), la lista del PC donde participaban Oscar Landi e Isidoro Cheresky ${ }^{21}$. Sin embargo, desde su participación en la FUBA y la FUA, el FAU formó parte de las nutridas movilizaciones que se realizaron en 1965 para exigir mayor presupuesto universitario y repudiar la invasión de EEUU a Santo Domingo, como en la recordada marcha del 12 mayo donde fue asesinado el militante comunista y estudiante de medicina Horacio Daniel Grinbank. En esa oportunidad, la CGT -en pleno Plan de Lucha- convergió con la FUA en una movilización al Congreso repudiando la injerencia estadounidense y reclamando la no aprobación de la participación argentina en la incipiente Fuerza Interamericana de Paz (Califa, 2014: 262).

Luego del alejamiento de Hopen, Grabois se convirtió en el referente del FAU. Su presencia en los encuentros intercentros de la FUA en 1965, le permitieron a la agrupación establecer dos contactos políticos que serían importantes unos años después ${ }^{22}$. El primero era la Agrupación Reformista Universitaria (ARAU) de la Facultad de Ciencias Matemáticas de Rosario, donde tenían protagonismo Eduardo Ceballos y Hernán Pereyra, presidentes del centro de estudiantes en distintas oportunidades ${ }^{23}$. Mientras el segundo, eran los militantes reformistas de la Facultad de Medicina de Córdoba agrupados en torno a Rodolfo Vittar y Luis Daichman. El FAU, los rosarinos y los cordobeses fueron la columna vertebral de la fundación del FEN en 1967, cuando decididamente se propusieron vincularse al peronismo desde el movimiento estudiantil. Luego extendieron sus redes militantes a Mar del Plata, Mendoza y Tucumán. Además, en la UBA llegaron a incorporar a sus filas a Renovación Reformista (RR), agrupación que dirigía el centro de estudiantes de Ciencias Económicas bajo la presidencia de Carlos Peola (Grabois, 2014: 190).

Más allá de estas ramificaciones, lo importante es resaltar que el establecimiento del FEN como una agrupación de "pasaje al peronismo" fue posible, en parte, porque sus principales núcleos provenían de una nueva izquierda estudiantil que en los años previos al golpe de Onganía había sido sacudida por la gesta cubana y había abandonado la vieja actitud antiperonista del reformismo. Sintomático de esta cuestión, fue el VII Congreso Nacional de Estudiantes de la FUA realizado en Buenos Aires entre el 8 y 12 de octubre de 1965. Sus resoluciones expresaban un apoyo explícito al Plan de Lucha de la CGT y al gobierno de Cuba. También acompañaban las clásicas banderas de

PSAV y militantes de PO relacionados a Bengochea. Como dijimos, a esta sector pertenecía Hopen, el líder del LIM (Rot, 2010: 197).

${ }^{21}$ Pueden consultarse documentos del FAU en Grabois (2014: 143 y 147). ARFYL ya había ganado las elecciones estudiantiles en 1964, el mismo año de su creación (Buchbinder, 1997: 213).

${ }^{22}$ El FAU acudía a las reuniones de la FUA porque participaba en la "secretaría de relaciones" de la comisión directiva del CEFYL (Grabois, 2014: 172).

${ }^{23}$ La Facultad de Ciencias Matemáticas de Rosario abarcaba las carreras de Ingeniería, Arquitectura y Ciencias Exactas. Su centro estudiantil era el más importante y numeroso de Rosario. ARAU ganó su conducción en 1966 y 1968 (Grabois, 2014: 158). 
autonomía, gobierno tripartito, participación estudiantil y libertad de cátedra con otras reivindicaciones. Entre ellas, sobresalían las críticas al "limitacionismo" por la escasez de presupuesto y las trabas al ingreso universitario, además de su impugnación a las políticas "cientificistas" que supuestamente ponían a las casas de estudio al servicio de los organismos internacionales. Todo esto en medio de una gran demanda política que llamaba a emprender la liberación nacional y social en Argentina (Ceballos, 1985: 81 y 107).

\section{De la Unión Nacional de Estudiantes a la Corriente Estudiantil Nacional y Popular}

El FEN no fue la única agrupación que cambió la perspectiva del peronismo en la UBA tras la intervención de Onganía. El 10 de agosto de 1968 se constituyó en la ciudad de Rosario la Unión Nacional de Estudiantes (UNE). La nueva entidad surgió por la confluencia entre la Liga Humanista de Buenos Aires (LHBA), la Unión de Estudiantes del Litoral (UEL) y las filiales del Integralismo radicadas en Córdoba, Santa Fe, San Luis y el Nordeste. Los principales referentes de UNE fueron el humanista porteño Julio Bárbaro y el integralista cordobés Carlos Azócar ${ }^{24}$. El primero era un estudiante de Agronomía de la UBA y de Ciencias Políticas de la Universidad del Salvador que en 1963 se había convertido en secretario general de la LHBA y en 1966 en su presidente. En esa primera mitad de los sesenta, los humanistas habían obtenido la conducción del centro de estudiantes de Ciencias Económicas -en aquel momento la facultad más grande de América Latina- y dos personalidades de su tendencia política, Julio Olivera e Hilario Fernández Long, llegaron a ser rectores de la UBA (Bárbaro, 2009: 40-41 $)^{25}$. En esos años, los humanistas también participaron en las demandas por mayor presupuesto universitario junto a reformistas e incluso fueron uno de los convocantes a la gran movilización del 12 de mayo de 1965, donde convergieron la FUA y la CGT bajo la consigna "Ningún soldado argentino en Santo Domingo"26. Si bien no cesaron las diferencias entre humanistas y reformistas, estos contactos tendieron a diluir el fuerte enfrentamiento que habían tenido unos años atrás frente a la instauración de universidades privadas; medida que había terminado de hacer realidad el ex presidente Arturo Frondizi con la ley 14.557, la cual reglamentó el artículo 28 del decreto 6.403 de la dictadura del general Aramburu.

Como en el caso del FEN, el surgimiento de la UNE y su acercamiento al peronismo no pueden comprenderse sin tener como referencia las transformaciones suscitadas en el ambiente político-universitario porteño con anterioridad a 1966. En 1958, asumió el papado Ángelo Giuseppe Roncalli, quien eligió el nombre de Juan

${ }^{24}$ Para una cobertura sobre la constitución de UNE, puede consultarse: "La semana estudiantil", en Semanario $C G T, \mathrm{~N}^{\circ} 17,22$ de agosto 1968.

${ }^{25}$ Entrevista a Julio Bárbaro, C.A.B.A., 21/01/2016. En 1965, los humanistas perdieron la conducción del centro de estudiantes que habían obtenido tres años antes frente a RR, la agrupación reformista encabezada por Peola que luego del golpe se integró al FEN de Grabois.

${ }^{26}$ El reclamo por mayor presupuesto universitario fue una demanda histórica del movimiento estudiantil, pero se agudizó en la primera mitad de los sesenta. Desde 1963, esto llevó a una unidad entre reformistas y humanistas en torno al reclamo. (Califa, 2014: 246 y 262). 
Dip. Antecedentes y orígenes de las primeras experiencias de peronización en la UBA. 1966 - 1970.

XXIII para encabezar la curia romana luego de la muerte de Pío XII. Si bien el nuevo Papa fustigó la experiencia cubana, su sorpresiva convocatoria e impulso al Concilio Vaticano II produjo resonancias importantes en el mundo católico argentino. Las nuevas encíclicas y debates llevaron a una revalorización de la doctrina social de la Iglesia y a una apertura hacia la "modernidad", la cual implicó un diálogo del catolicismo con otras ideologías y una crítica a las desigualdades producidas en el sistema capitalista ${ }^{27}$.

Todo este proceso se tradujo de diferentes maneras en distintos lugares del mundo y América Latina. En el tema particular que nos ocupa, son destacables dos experiencias. La primera es la "Línea de Apertura" que encabezó Horacio Sueldo en la Democracia Cristiana (DC), al intentar conformar una plataforma electoral con Raúl Matera -dirigente de la rama política del movimiento peronista- en las elecciones presidenciales de 1963. A pesar de que la coalición no pudo concretarse por la proscripción de Matera, el intento mostraba un alejamiento de las posiciones más antiperonistas que habían caracterizado a la DC desde su origen en 1954, en medio del conflicto entre la Iglesia Católica y el último gobierno de Perón (Castro y Salas, 2011: 11 y 14). Los humanistas como Bárbaro, si bien no eran necesariamente militantes orgánicos de la DC ni tampoco integraban una organización oficial como la Acción Católica Argentina, no fueron ajenos a los debates que generó la "Línea de Apertura" de Sueldo ${ }^{28}$.

La segunda experiencia destacable en el marco del Concilio Vaticano II fue que el "diálogo" entre cristianos y marxistas iniciado en Europa tuvo manifestaciones propias en la UBA ${ }^{29}$. Un caso relevante fue el extenso debate que entablaron León Rozitchner y Conrado Eggers Lan a principios de los sesenta. El primero era doctor en filosofía, había integrado la revista Contorno y militaba en el MLN. Mientras el segundo era un reconocido profesor de la Facultad de Filosofía y Letras que en su juventud había sido miembro de Acción Católica y luego se enroló en la DC, en donde realizó una militancia antiperonista que lo llevó a estar unos días detenido antes del golpe de 1955 (Eggers Brass, 2012: 38). El debate con Rozitchner fue producto del reportaje que brindó Eggers Lan para el segundo número del Correo de C.E.F.Y.L en octubre de 1962. En esa entrega, los propios estudiantes reformistas consideraban sus reflexiones como valiosos aportes para pensar la realidad. La tesis principal de Eggers Lan sostenía que el enfrentamiento entre marxistas y cristianos era "artificioso". A su entender, estos últimos también bregaban por acabar con la "enajenación" y alcanzar la realización plena de la persona humana, al liberarla del principal factor que la oprimía según los Evangelios: "la riqueza". En este punto, llegaba a afirmar que el marxismo no era más que una "secularización" de los motivos "más profundos" del pensamiento judeo-cristiano ${ }^{30}$.

Luego de esta entrevista, comenzó la polémica y se extendió hasta 1964 en el segundo, tercer y cuarto número de la revista Pasado y Presente, que en ese entonces

\footnotetext{
${ }^{27}$ Pueden consultarse varios trabajos, entre ellos Morello (2003), Deschner (2004) y Verbitsky (2008).

${ }^{28}$ Entrevista a Julio Bárbaro, C.A.B.A., 21/01/2016.

${ }^{29}$ Según José Pablo Martín el diálogo entre católicos y marxistas comienza en la Argentina en 1962 (2010: 182-183).

30 “Cristianismo y marxismo", en Correo de CEFYL, № 2, octubre 1962, pp. 1-2.
} 
impulsaban jóvenes intelectuales disidentes del PC, como José Arico y Juan Carlos Portantiero. El debate se tituló "Marxismo o cristianismo" por el tono que finalmente adquirió. De acuerdo a la respuesta de Rozitchner, Eggers Lan caía en un "confusionismo moralizante" y el cristianismo era una comunidad que mantenía el dominio entre los hombres ${ }^{31}$. A su vez, aquél replicaba en duros términos al calificar a Rozitchner como un "marxista de derecha", que no comprendía la "madurez ideológica" colectiva en la que participaban los cristianos. Eggers Lan sostenía que este cambio lo había llevado a estrechar lazos con marxistas y a darse cuenta que su "teorización" y militancia contra el gobierno depuesto en 1955 habían sido un error ${ }^{32}$. Si bien el intercambio no se dio en buenos términos, sirvió para impulsar otras actividades similares, como la realizada en el aula magna de Filosofía y Letras en octubre de 1965, cuando el asesor de Acción Católica en la Facultad de Ciencias Económicas, Carlos Mugica, compartió una mesa de debate junto a Guillermo Tedeschi y los marxistas Juan Rosales y Fernando Nadra.

Con estos antecedentes, luego del golpe de 1966 Bárbaro impulsó los Grupos Marcha en el local de la Fundación Argentina para la Promoción del Desarrollo Económico y Social (FAPES), que le facilitaron contactos suyos de la DC. En su organización, también participaron ex dirigentes de la juventud demócrata cristiana como Norberto Habegger, Oscar De Gregorio y Horacio Mendizábal. Los Grupos Marcha tenían el objetivo de formar universitarios y debatir los cruces entre política y religión. En sus encuentros, participaban invitados con distintas trayectorias: el propio Eggers Lan, el socialista Gregorio Selser, el sindicalista peronista Amado Olmos, el padre Miguel Mascialino y hasta políticos del Partido Socialista de la Izquierda Nacional (PSIN), como Jorge Abelardo Ramos y Jorge Enea Spilimbergo (Bárbaro, 2009: 59).

El contacto con otras vertientes políticas que fomentaban los Grupos Marcha, también tuvo lugar en la UNE. Al poco tiempo de su creación, se adhirió a sus filas la Corriente Estudiantil Nacional y Popular (CENAP). La misma surgió de un desprendimiento del FEN promovido por Poggiese ${ }^{33}$. Él había militado en la Unión de Estudiantes Secundarios (UES) de Punta Alto, aunque en sus primeros años como estudiante de Derecho de la UBA recaló en el Movimiento Universitario Reformista (MUR). A principios de los sesenta, se vinculó al MIRA y formó junto a otros alumnos la Corriente Estudiantil Antiimperialista (CEA). Como indicamos anteriormente, en esos años los militantes vinculados al MIRA también tenían presencia en la Facultad de Filosofía y Letras a través del TAU, la agrupación que formó el FAU junto al LIM. Esta unión fue el antecedente directo del FEN. Sin embargo, al momento de su constitución, el CEA y algunos militantes del TAU decidieron no encolumnarse detrás de Grabois y optaron por formar la CENAP, a la que también se sumó, gracias a las distintas

${ }^{31}$ Rozitchner, L, "Marxismo o cristianismo" en Pasado y Presente, № 2-3, julio-diciembre 1963, pp. 113133.

${ }^{32}$ Eggers Lan, C., "Acerca de 'marxismo o cristianismo'. Respuesta a la derecha marxista", en Pasado y Presente, $\mathrm{N}^{\circ} 4$, Año 1, enero - marzo 1964, pp. 376-382.

${ }^{33}$ Entrevista a Héctor Poggiese, C.A.B.A., 12/01/2016; "Nos divertíamos como locos. Entrevista a Héctor Poggiese", en Política, cultura y sociedad en los '70, $\mathrm{N}^{\circ} 2$, julio 1997, p. 23. El surgimiento de CENAP también es reseñado en: "Herederos de la práctica popular", en Primera Plana, N 488, 6 de junio 1972. 
Dip. Antecedentes y orígenes de las primeras experiencias de peronización en la UBA. 1966 - 1970.

alianzas políticas que había establecido Poggiese, la Tendencia Universitaria Popular de Arquitectura y Urbanismo (TUPAU) ${ }^{34}$. Finalmente, al adherirse la CENAP a la UNE, ésta ensanchó sus bases militantes más allá de la vertiente socialcristiana, al sumar sectores reformistas que en su mayoría pertenecían a una izquierda que no respondía al PC.

\section{Las Juventudes Argentinas para la Emancipación Nacional}

Las Juventudes Argentinas para la Emancipación Nacional (JAEN) fue otra de las agrupaciones que modificó la situación del peronismo en la UBA luego del golpe de Onganía. El JAEN se fundó en el bar "La Perla" del barrio de Once en marzo de 1967 (Larraquy y Caballero, 2011: 63) ${ }^{35}$. A diferencia del FEN, UNE y CENAP, desde sus inicios no se concibió como una agrupación estudiantil, sino como una estructura política juvenil más amplia que pretendía intervenir en distintos frentes, entre ellos el universitario. Su principal referente fue Rodolfo Galimberti, en ese entonces estudiante de la Facultad de Derecho. Aunque el primer contacto del líder de JAEN con el peronismo no se originó en dicha organización. Galimberti procedía de una familia nacionalista y católica pro peronista. A principios de los sesenta, había comenzado a militar en el Movimiento Nacionalista Tacuara (MNT), una agrupación con tintes fascistas y anticomunistas que era conducida por Alberto Ezcurra Uriburu (Larraquy y Caballero, 2011: 45-46). En aquel momento, algunos integrantes del MNT ya habían abandonado las posturas más elitistas y se habían acercado al sindicalismo combativo peronista, como en la toma del frigorífico Lisandro de la Torre de 1959. Esta aproximación llevó a la ruptura de la agrupación de Ezcurra y al surgimiento del Movimiento Nacionalista Revolucionario Tacuara (MNRT) a fines de 1962. Al año siguiente, este grupo terminó de hacerse conocido con el asalto armado al transporte de caudales del Policlínico Bancario. Luego de la operación, el propio MNRT se definió en la revista 4161 de la JUP como una organización que reconocía el liderazgo de Perón y pretendía imponer con la lucha armada y la movilización popular el programa de Huerta Grande ${ }^{36}$. Galimberti no integró directamente esta facción que encabezaron Joe Baxter y José Luis Nell, pero no fue ajeno al debate generado en el nacionalismo argentino cuando el MNRT trazó una línea de acercamiento al marxismo y al peronismo de izquierda (Bozza, 2014: 68). En 1964, Galimberti participó en la procesión hasta Luján para rezar por la frustrada vuelta de Perón, impulsada por el Comando de Organización (CdeO) de Brito Lima ${ }^{37}$. Al año siguiente, una vez anotado en la facultad, se convirtió en un seguidor "periférico" del

\footnotetext{
${ }^{34}$ Entrevista a Roberto Corvaglia, C.A.B.A., 11/09/2015. Corvaglia era un militante de TUPAC que se integró al CENAP. También pueden consultarse sus testimonios en Baschetti (2016: 186-190).

${ }_{35}$ Entrevista a Ernesto Jauretche, La Plata, 15/01/2016.

36 "MNRT: violencia revolucionaria", en 4161, N 2, junio 1964.

${ }^{37}$ Brito Lima había sido afiliado de la UES y el CdeO hundía sus raíces en grupos de activistas de la JP. Cuando los dispersos núcleos juveniles de la Resistencia se agruparon en una Mesa Ejecutiva en 1959, las secretarías pasaron a funcionar como una suerte de reparto de poder interno. Brito Lima se erigió en líder de un grupo dirigido conjuntamente con Rubén Macchiavello, Pablo Flores y Domingo Paleo. En un congreso realizado en el Sindicato del Calzado en 1961, este sector perdió una ajustada votación interna para la dirección de la JP. Fue entonces cuando Brito Lima se escindió del resto de la Mesa Ejecutiva con la Secretaría de Organización, de la cual devino el nombre de su agrupación (Denaday, 2016: 1-21).
} 
Sindicato Universitario de Derecho (SUD) que lideraba Antonio Valiño y participaban varios militantes de Tacuara (Larraquy y Caballero, 2011: 61).

Desde esta trayectoria previa, Galimberti se hizo cargo de la jefatura del JAEN. No obstante, también integraron la agrupación otros militantes importantes que contribuyeron a delimitar su perfil político. Entre ellos, había dos profesores de la Universidad del Salvador. Uno era Augusto Pérez Lindo, quien dictaba clases en la materia Introducción a las Ciencias Políticas y había dado sus primeros pasos en la Unión Nacionalista de Estudiantes Secundarios, el antecedente directo de la formación del MNT en 1957. El propio Pérez Lindo había sido quien acercó a Galimberti a la filas capitaneadas por Ezcurra. El otro docente era Carlos Grosso, un ex seminarista jesuita y licenciado en letras (Larraquy y Caballero, 2011: 45-46). Él escribió uno de los primeros documentos importantes de JAEN que sería publicado en 1969 por la editorial Sudestada, titulado "El movimiento nacional y la Iglesia" 38 . En sus páginas, JAEN se reconocía como parte de un sector católico "esclarecido" que bregaba por la "liberación" de América Latina. Postura que acompañaban con una fuerte crítica a la institución eclesiástica por haber enfrentado al peronismo en los años cincuenta y provocado una ruptura que, a su entender, aún no se había vuelto a recomponer ${ }^{39}$.

Otro militante importante de JAEN fue Ernesto Jauretche, el sobrino de un reconocido ensayista que había sido dirigente de la Fuerza de Orientación Radical de la Joven Argentina (FORJA) y presidente del Banco de la Provincia de Buenos Aires durante el primer gobierno de Perón. El joven Jauretche, egresado de la Escuela Técnica Otto Krause, desde un primer momento estuvo vinculado al peronismo por su participación en la UES, por la trayectoria política de su tío Arturo e incluso de sus propios padres. Ya en los tiempos de JAEN, Jauretche estaba inscripto en la carrera de Historia de Filosofía y Letras y trabajaba como periodista en El Economista, donde conoció a quien fue el principal financista de las actividades de JAEN, Diego Muniz Barreto. Heredero de una gran fortuna familiar y otrora activo militante antiperonista, Muniz Barreto trabajaba en ese entonces junto al secretario Legal y Técnico de Onganía, Roberto Roth. Conoció a Jauretche cuando le brindó información para revelar que el ministro de Economía, Adalbert Krieger Vasena, formaba parte del directorio de la empresa Swift-Deltec. Más allá del hecho particular, este caso era sintomático de la política de JAEN, la cual intentaba tender puentes con distintos sectores, involucrados tanto con la Iglesia Católica, como en ámbitos políticos y militares ${ }^{40}$.

El último integrante relevante de JAEN que no podemos pasar por alto era Jorge Raventos. A diferencia del resto, había ingresado al PSIN de Ramos a principios de los sesenta, al poco tiempo de su fundación". Era uno de los responsables del "núcleo" partidario de Filosofía y Letras, el cual también integraban el ex militante socialista Ernesto Laclau y la hija de un reconocido intelectual expulsado del PC por adherir al gobierno de Perón en los años cuarenta: Adriana Puiggrós ${ }^{42}$. Desde sus inicios, la línea

\footnotetext{
${ }^{38}$ Sudestada era una editorial que pertenecía a Eduardo Luis Duhalde y Rodolfo Ortega Peña.

39 JAEN, "El movimiento Nacional y la Iglesia", en Cuadernos del Movimiento Nacionalista Pampero, Bs.As., Sudestada, 1969, pp. 15-16.

${ }^{40}$ Entrevista a Ernesto Jauretche, La Plata, 15/01/2016. También véase Salas (2014: 55).

${ }^{41}$ El PSIN se fundó en 1962 (Tarcus, 2007:549).

${ }^{42}$ Entrevista a Adriana Puiggrós, C.A.B.A., 09/02/2016.
} 
Dip. Antecedentes y orígenes de las primeras experiencias de peronización en la UBA. 1966 - 1970.

política del PSIN buscaba formar una estructura partidaria independiente que sea capaz de orientar al peronismo hacia el socialismo. Por eso, no era extraño que propiciara en sus frentes el acercamiento a las manifestaciones del sindicalismo peronista, tal como hizo el 22 de mayo de 1964 cuando impulsó desde el CEFYL la toma del rectorado de la UBA en apoyo al Plan de lucha de la CGT. A mediados de los sesenta, Raventos se alejó del PSIN, formó por un breve tiempo el Partido Revolucionario de la Izquierda Nacional (PRIN) y luego la revista Patria Grande, hasta que finalmente se incorporó al JAEN (Regali, 2012: 318-319). Como se observa en este último caso, y en otros descriptos anteriormente, las fronteras ideológicas de las nuevas organizaciones eran porosas y permitían el ingreso de militantes de distintas trayectorias, al dejar atrás antagonismos que hasta hacía poco parecían irreconciliables, como reformistas versus católicos y peronistas versus antiperonistas.

El intento de formar una agrupación juvenil amplia que sea capaz de influir en diversos espacios, condujo a JAEN a crear sus propios frentes universitarios. Aunque éstos, al igual que el conjunto de la organización, fueron pequeños y sólo nuclearon un puñado de militantes. En 1967, Galimberti junto a Héctor Mauriño, Ricardo Mitre y Luis Alberto Vuistaz armaron el Frente 17 de Octubre en la Facultad de Derecho. El primero había cursado el secundario con Galimberti en el Instituto Domingo Faustino Sarmiento y los otros dos llegaron al JAEN de la mano de Luis Alberto Spinetta y Emilio Del Guercio, dos militantes periféricos de la agrupación que estaban inscriptos en la Escuela de Bellas Artes. Ambos habían sido compañeros de Mitre y Vuistaz en el Instituto San Román. Dos años después, el propio Galimberti decidió reforzar la incursión de JAEN en la universidad e impulsó la formación del Comando General Juan José Valle en Filosofía y Letras, donde terminó recalando un estudiante de Historia apodado "Chacho": Carlos Álvarez (Larraquy y Caballero, 2011: 65-66 y 79). De esta manera, la aparición de JAEN seguía sumando siglas a un escenario políticouniversitario donde parecía adquirir mayor peso el término "nacional" y acrecentarse el número de agrupaciones que se mostraban afines al peronismo.

\section{Estudiantes peronistas de la CGT de los Argentinos}

Hasta el momento analizamos cómo cambió el panorama del peronismo en la UBA tras el golpe de Onganía, a raíz de la aparición de un conjunto de agrupaciones estudiantiles, cuyos principales referentes procedían de espacios católicos, nacionalistas o reformistas. Pero todavía falta abordar una cuestión importante que permite entender aún más esta experiencia ¿cómo interpretaban al peronismo los estudiantes que apenas habían vivido su temprana infancia en las primeras presidencias de Perón y en su mayoría provenían de círculos sociales que habían respaldado su derrocamiento en 1955? Para responder a este interrogante, no basta con señalar que varios integraban ámbitos militantes que abandonaron sus posturas antiperonistas con anterioridad a 1966. También es necesario abordar los posicionamientos políticos concretos que tomaron en el marco de la dictadura de Onganía. Especialmente, cuando apareció la CGT de los 
Argentinos (CGTA) y se articuló un ámbito de oposición frontal al régimen militar que incluía una parte importante del activismo estudiantil.

Este proceso no fue lineal dado que tardó en generarse una convocatoria amplia contra el gobierno militar. Como apuntamos, la asonada del 28 de junio de 1966 contó con un respaldo social, político y mediático importante. En este contexto, la UBA fue la única institución pública en poner reparos contra el golpe. Mediante una declaración, el rector humanista Fernández Long junto a la mayoría del Consejo Superior calificó al 28 de junio como un "día aciago" y llamó a la defensa de la autonomía universitaria ${ }^{43}$. Tan sólo un mes después, el gobierno finalmente decretó la intervención de todas las casas de estudio y desalojó violentamente la toma de algunas facultades porteñas que intentaban frenar la medida. Luego de "La noche de los bastones largos", el pico más alto de protestas se vivió en Córdoba en la movilización nacional convocada por la FUA el 7 de septiembre de 1966; pero la respuesta fue la misma y esta vez el accionar policial produjo la muerte del militante estudiantil radical Santiago Pampillón. Desde el mes de octubre, la oposición comenzó su declive y en abril del año siguiente Onganía finalmente puso en vigencia una nueva normativa universitaria que prohibía cualquier tipo de actividad política en las aulas.

En el plano nacional, recién en 1968 comenzaron a revitalizarse las protestas contra el régimen militar. Un punto clave fue la realización del congreso normalizador "Amado Olmos" de la CGT celebrado el 28 de marzo. En el mismo obtuvieron mayoría los sindicatos que propugnaban una oposición abierta a Onganía y designaron como secretario general a Raimundo Ongaro, dirigente de la Federación Gráfica Bonaerense. El vandorismo en minoría impugnó la decisión, quedando conformadas de hecho dos CGT: Azopardo y de los Argentinos ${ }^{44}$. La relevancia de la CGTA radicó en la propuesta de crear un polo opositor amplio a la dictadura con tintes anticapitalistas y antiimperialistas. Este proyecto lo manifestó desde un inicio en el programa " $1^{\circ}$ de mayo: mensaje a los trabajadores y al pueblo argentino" que publicó el número inaugural del Semanario CGT, su órgano de difusión oficial a cargo del mismo Ongaro y el secretario de prensa de la central, Ricardo De Luca, bajo la dirección periodística de Rodolfo Walsh ${ }^{45}$. El plan de la CGTA retomaba implícitamente los programas de La Falda (1957) y Huerta Grande (1963) del sindicalismo combativo peronista, ya que proponía una nacionalización de

\footnotetext{
43 "Declaración de la Universidad de Buenos Aires", 28 de junio de 1966.

${ }^{44}$ La CGT se encontraba intervenida a partir del fracaso del plan de lucha de 1967, por lo que se convocó a un congreso en marzo de 1968 con el fin de normalizarla. El objetivo del encuentro era conformar un nuevo secretariado, elegido por mayoría y de forma representativa. En los tiempos previos, había comenzado a consolidarse una fuerte corriente interna o "línea dura", conformada por un grupo de activistas y dirigentes sindicales que bajo la bandera de "recuperar la CGT para la defensa de los trabajadores" recorrieron el interior del país y fueron acumulando fuerzas. Esta rama era encabezada en ese momento por Amado Olmos, pero también adherían a ella Ongaro, Julio Guillán y Jorge Di Pascuale. Los cuatro eran representantes del sindicalismo combativo peronista que criticaba duramente la política de negociación de Vandor con el régimen militar (Sotelo, 2012: 163).

${ }^{45}$ Entre mayo de 1968 y febrero de 1970, fueron publicados 55 números del Semanario CGT. Bajo la dirección periodística de Walsh, había un equipo de redacción conformado por periodistas como Horacio Verbitsky y Rogelio García Lupo.
} 
Dip. Antecedentes y orígenes de las primeras experiencias de peronización en la UBA. 1966 - 1970.

sectores clave de la economía y una erradicación de las estructuras capitalistas de las que no podía surgir "ni una sociedad justa ni cristiana". A su entender, lo que había que realizar era un "sindicalismo integral" que anhele la "liberación nacional" y el "control del poder", no uno solamente atento a cuestiones gremiales como "convenios" y "colonias de vacaciones". Desde esta posición, la central de Ongaro convocaba a "empresarios nacionales, pequeños comerciantes, universitarios, artistas y religiosos" a sumarse a ese programa y a crear un frente contestatario a la dictadura de Onganía ${ }^{46}$.

Si bien la CGTA estuvo lejos de llevar adelante este ambicioso proyecto, estableció una verdadera articulación con otros actores políticos y sociales, especialmente, con el movimiento estudiantil. No por nada, sus adversarios la trataban socarronamente como "la CGT de los estudiantes" y llegó a establecer en sus propias filas una comisión "obrero-estudiantil" ${ }^{47}$. Este vínculo en buena medida fue posible por los contactos que empezaron a tejerse en las protestas de 1968, como las desatadas el 28 de junio cuando la CGTA convocó a un acto en Plaza Once y en otros lugares del interior del país, para repudiar a la dictadura en su segundo aniversario. En la misma participaron la FUA y el FEN, el cual tuvo entre los heridos por la represión policial a sus dos principales dirigentes porteños: Grabois y Peola ${ }^{48}$. También, en el mes de septiembre, al cumplirse dos años del asesinato de Pampillón, confluyeron en distintas protestas la FUA, FEN, UNE y FANDEP con la CGTA ${ }^{49}$. Como corolario de estos encuentros, el Semanario CGT publicó a fin de año una serie de entrevistas para ofrecer un panorama de la universidad y de las organizaciones estudiantiles con las que entablaba acciones. Los reporteados fueron Bárbaro por la UNE, Grabois por el FEN y Jorge Rocha por la FUA ${ }^{50}$. Este último era un estudiante de Derecho de la UBA que integraba el Comité Nacional de Recuperación Revolucionaria del Partido Comunista de la Argentina (CNRR), una escisión que había sufrido la Federación Juvenil Comunista (FJC) el 6 de enero de 1968, la cual al poco tiempo pasaría a llamarse Partido Comunista Revolucionario (PCR) y sus filas estudiantiles Frente de Agrupaciones Universitarias de Izquierda (FAUDI) ${ }^{51}$.

A pesar de la diversidad de sus trayectorias y anclajes ideológicos, en estas entrevistas los tres estudiantes compartían con la CGTA la actitud de enmarcar sus demandas particulares en un proyecto político que situaba su horizonte en la idea de

46 “ $1^{\circ}$ de mayo: mensaje a los trabajadores y al pueblo argentino", en Semanario CGT, № 1,1 de mayo 1968.

${ }^{47}$ Según la revista Siete Días Ilustrados, una "cáustica humorada" de los "mandarines vandoristas" de la CGT Azopardo era la pregunta: “¿CGT de los argentinos o CGT de los estudiantes?”. "La CGT de los estudiantes", en Siete Días Ilustrados, julio 1968. Reproducido en http://www.magicasruinas.com.ar/ revdesto069.htm.

48 “Azopardo medita, el pueblo lucha”, en Semanario CGT, N 10, 4 de julio 1968.

${ }^{49}$ El 10 de agosto se habían juntado estos sectores estudiantiles en la ciudad de Rosario para coordinar una semana de protesta del 6 al 12 de septiembre en articulación con la CGTA. "La semana estudiantil", en Semanario CGT, $\mathrm{N}^{\circ}$ 17, 22 de agosto 1968.

50 "Hablan los estudiantes", Semanario CGT, N 33, 12 de diciembre 1968; "Los estudiantes son una columna de la liberación", en Semanario CGT, №34, 19 de diciembre 1968.

${ }^{51}$ Esta ruptura del PC pasó a llamarse PCR desde el 10 de marzo de 1969. Fue la mayor escisión de la FJC en los sesenta y llevó a que los comunistas pierdan la conducción de la FUA en manos de sus propios ex compañeros de ruta (Gilbert, 2009: 520 y 528). 
liberación. Cada uno lo explicaba a su manera. Rocha sostenía que la movilización por el 50 aniversario de la Reforma del ' 18 realizada el 14 de junio de 1968 y el paro de la CGTA convocado diez días después, demostraban la creciente actividad de los estudiantes y los obreros contra la dictadura. Pero agregaba que todavía faltaba "integrar" y "superar" los postulados reformistas para ubicar la problemática estudiantil en un marco de "liberación nacional e internacional", tal como lo habían hecho "precursores" como Julio Antonio Mella y José Carlos Mariátegui ${ }^{52}$.

Grabois y Bárbaro, por su parte, sostenían que la intervención de Onganía había acabado con la política reformista de la "isla universitaria", que sólo llevaba a prestarle atención a las demandas gremiales del estudiantado sin tener en cuenta el contexto político más amplio. De todas maneras, lo más interesante no eran estas ideas que incluso podían encontrarse con anterioridad a 1966, sino que la CGTA les ofreció una opción tangible de lo que entendían por peronismo y "conciencia nacional". Esto quedaba claro cuando Grabois sostenía que el movimiento estudiantil estaba eludiendo el error de 1930, 1945 y 1955, al comprender que el eje no era "reforma o anti-reforma", sino "imperialismo o peronismo revolucionario", al que definía como la "vanguardia de la clase obrera". A su entender, asumir una "postura nacional" significaba hacer realidad el programa de la CGTA e integrar a los estudiantes a un frente hegemonizado por los sectores combativos del sindicalismo peronista, para acabar con la situación neocolonial de la Argentina y emprender el camino al socialismo ${ }^{53}$.

Por consiguiente, no era cualquier peronismo el que tenían en mente dirigentes como Bárbaro o Grabois. Su idea de ser peronistas radicaba en sentirse parte de un movimiento de liberación tercermundista y socialista. Varios analistas han sostenido que la Revolución Cubana jugó un papel clave en estas interpretaciones, al convertirse en un ejemplo concreto y latinoamericano de que al socialismo no lo hacían los partidos tradicionales de izquierda, sino los movimientos nacionales (Sigal, 1991: 201). El propio Grabois abonaba esta idea en otra entrevista de 1968 que brindó junto a Bárbaro y Peola para La Hora de los Hornos, la película del Grupo Cine Liberación ${ }^{54}$. En ella, el dirigente del FEN decía que el mayor legado de la gesta cubana para los "marxistasleninistas" como él, fue hacerlos comprender que el peronismo era el camino nacional al socialismo ${ }^{55}$.

Pero más allá de la Revolución Cubana, es relevante destacar que la CGTAjugó en sí misma un papel importante para los estudiantes que emprendieron en esos años el pasaje al peronismo. La central de Ongaro les ofreció una opción concreta desde el

\footnotetext{
52 "Los estudiantes son una columna de la liberación", en Semanario CGT, № 34, 19 de diciembre 1968.

53 "Hablan los estudiantes", en Semanario CGT, No 33, 12 de diciembre 1968. A pesar de los significados que otorgaban estudiantes como Grabois a la CGTA, no debe perderse de vista que aunque la línea peronista era la mayoritaria, la central de Ongaro predicó una amplitud ideológica, la cual dio lugar y reconocimiento a distintas corrientes políticas al interior de la central (Sotelo, 2012: 167).

${ }^{54}$ Varias experiencias de militancia artística estuvieron vinculadas a la CGTA, como la del pintor Ricardo Carpani y la del Grupo Cine Liberación. Los dibujos y las películas se utilizaban como herramientas de formación o en las mismas actividades políticas.

${ }^{55}$ Solanas, F., y Getino, O., La Hora de los Hornos, Grupo Cine Liberación, 1968.
} 
Dip. Antecedentes y orígenes de las primeras experiencias de peronización en la UBA. 1966 - 1970.

mundo obrero, en donde podían confluir peronistas, marxistas y cristianos. Esto era justamente lo que resaltaba Bárbaro en el mismo film de Fernando Solanas y Octavio Getino que circuló de manera clandestina, pero ampliamente entre la militancia de aquel entonces $^{56}$. No era casual que subrayara este punto, debido a que en la CGTA era posible encontrar a Walsh, con un pasado reciente vinculado a la formación de Prensa Latina, o a un dirigente sindical cristiano y peronista como Ongaro. A esto se sumaba que la central tenía contactos políticos con el Movimiento de Sacerdotes para el Tercer Mundo $(\mathrm{MSTM})^{57}$ y con la revista Cristianismo y Revolución dirigida por Juan García Elorrio, en la cual se expresaban los sectores de filiación católica más identificados con la lucha revolucionaria en su vertiente $\operatorname{armada}^{58}$. Ambas experiencias, como la misma CGTA, estuvieron influenciadas por el cauce de politización que siguió una parte de la corriente posconciliar en la segunda mitad de los sesenta, cuando el sucesor de Juan XXIII, el Papa Paulo VI, inauguró una nueva etapa con la encíclica Populorum Progressio (Castro y Salas, 2011: 31). En su artículo 31, llegaba afirmar que la insurrección violenta era justificada en dictaduras "evidentes y prolongadas".

\section{El fin de la CGTA y el sinfín de siglas del peronismo universitario}

El año 1969 trajo grandes levantamientos populares en el interior de país que dejaron un saldo de tres estudiantes muertos: Juan José Cabral, Adolfo Bello y Luis Blanco. Si bien el foco estuvo puesto en las provincias y especialmente en lo que después se conoció como el Cordobazo, también hubo protestas porteñas en menor escala donde convergieron la CGTA con militantes enrolados en la FUA, el FEN y la UNE. El 27 de junio, un día antes del tercer aniversario de la dictadura, volvió a producirse una fuerte manifestación en Buenos Aires contra la visita oficial de Nelson Rockefeller, el gobernador de Nueva York que acudió al país en representación del presidente estadounidense Richard Nixon. La jornada dejó un saldo de más de cien detenidos y el asesinato de Emilio Jáuregui, el secretario general del Sindicato de Prensa. Lo paradójico fue que esta etapa de grandes protestas no sólo marcó el principio del fin de Onganía, sino también de la CGTA. Al día siguiente del entierro de Jáuregui y de la marcha de silencio realizada el 29 de julio, la central fue intervenida y sus principales dirigentes detenidos. Los sucesos se produjeron paralelamente al asesinato de Vandor por un desconocido comando guerrillero. A esto se sumaría en 1970, la realización de un

\footnotetext{
${ }^{56}$ Ibídem.

${ }^{57}$ El mismo periódico de la CGTA reseñó los orígenes del MSTM. "Sacerdotes del Pueblo", en Semanario $C G T, \mathrm{~N}^{\circ} 33,12$ de diciembre 1968. Además publicó varias notas referidas a grupos o referentes católicos. Véase: $\mathrm{N}^{\circ} 31,28$ de noviembre 1968; $\mathrm{N}^{\circ} 35,29$ de diciembre 1968; $\mathrm{N}^{\circ} 39,20$ de febrero 1969, entre otros.

${ }^{58}$ La revista Cristianismo y Revolución, declaradamente mensual -aunque en lo real fue algo más irregular, llegando a veces a ser quincenal- se publicó entre septiembre de 1966 y septiembre de 1971. Fue dirigida durante sus primeros veintidós números por García Elorrio, ex seminarista y líder del Comando Camilo Torres, una organización donde se formaron buena parte de los dirigentes de Montoneros. En sus números pueden encontrarse varias referencias a la CGTA, pero una nota importante fue la extensa entrevista que le realizaron a Ongaro en 1969, donde éste repasó el itinerario recorrido por su central. "Habla Ongaro", en Cristianismo y Revolución, $\mathrm{N}^{\circ}$ 13, primera quincena abril 1969, pp. 14-24.
} 
nuevo congreso normalizador que, con el visto bueno de Perón, ungiría a José Ignacio Rucci y a Lorenzo Miguel como la nueva dirección unificada de la CGT.

En este contexto de fuertes manifestaciones y de desarticulación de la CGTA, la revista Cristianismo y Revolución publicó un documento del FEN y de la FUA, donde ambas organizaciones resaltaban los sucesos de mayo y junio de 1969 y tomaban posición ante el inminente IX Congreso Nacional de Estudiantes, el cual pretendía realizar la federación reformista encabezada por Rocha a fines de ese mismo año ${ }^{59}$. En sus documentos, los dos sectores compartían que Onganía estaba en retroceso por la unión entre obreros y estudiantes, pero sostenían que era necesario unificar a estos últimos en una única entidad nacional. Lo que los diferenciaba era la forma de concretarla. Mientras la FUA, bajo la conducción del FAUDI, planteaba que su congreso era el punto de partida para lograr una unidad que se simbolizara en las figuras del "Che" Guevara y el cura guerrillero colombiano Camilo Torres; el FEN se negaba a aceptar que reclamase esa exclusividad porque no era la única tendencia del movimiento estudiantil. A su entender, frente a ella se había gestado una "línea nacional" donde confluían reformistas y católicos. Por esta razón, se debía encontrar una plataforma que expresara verdaderamente a todas las fuerzas, sin ser bajo el sello de la FUA.

Pese a las visiones de unos y otros, estos llamados a la unidad no tenían correlato en la práctica del movimiento estudiantil. La propia FUA se dividiría al poco tiempo y las agrupaciones nacionales o peronistas estaban fuertemente fragmentadas. El escenario de la UBA era representativo al respecto. Si bien Bárbaro y Grabois tuvieron gran protagonismo en la articulación con la CGTA, en esta experiencia también participaron agrupaciones como FANDEP, CENAP y JAEN. A esto se sumó que a principios de los setenta aparecieron nuevos nucleamientos universitarios que complejizaron aún más el panorama. Algunos surgieron a instancias de agrupaciones donde tenían un papel importante dirigentes gremiales que habían integrado la CGTA, como los Comandos Estudiantiles Peronistas (CEP), creados a instancias de la Organización Peronista 17 de Octubre que lideraba el sindicalista telefónico Julio Guillán ${ }^{60}$. A ellos se incorporaron varios militantes del Movimiento Humanista Renovador (MHR) de Filosofía y Letras, como Norberto Ivancich, Marcelo Cerviño y Susana Ramus (Ramus, 2000: 14; Baschetti, 2007: 121). Otro caso fue el de la Agrupación de Estudiantes Peronistas (AEP), el frente universitario que impulsó el Movimiento Revolucionario Peronista (MRP). En su conducción tenía un rol destacado De Luca, el dirigente del Sindicato Argentino de Obreros Navales que actuó como secretario de prensa de la CGTA ${ }^{61}$.

\footnotetext{
59 "Hacia el Congreso Nacional de Unidad. La crisis del movimiento estudiantil. Llamamiento de la FUA (Federación Universitaria Argentina)", en Cristianismo y Revolución, $\mathrm{N}^{\circ}$ 22, enero 1970, pp. 21-26; "Declaraciones del FEN (Frente Estudiantil Nacional)", en Cristianismo y Revolución, $\mathrm{N}^{\circ}$ 22, enero 1970, pp. 32-34.

${ }^{60}$ Guillán había creado en octubre de 1969 la Coordinadora de Agrupaciones Gremiales y Organizaciones Políticas Peronistas. En marzo del año siguiente, el grupo adoptó el nombre de Organización Peronista 17 de Octubre y creó sus frentes específicos de militancia. De esta manera, en la universidad surgieron los CEP (Bartoletti, 2010: 207). Una reseña del surgimiento de los CEP, también puede encontrarse en: "Herederos de la práctica popular", en Primera Plana, N 488, 6 de junio 1972.

${ }^{61}$ El origen del MRP puede situarse hacia agosto de 1963, cuando Perón -a través de Héctor Villalón-
} 
Dip. Antecedentes y orígenes de las primeras experiencias de peronización en la UBA. 1966 - 1970.

Por otra parte, también aparecieron nuevos espacios a raíz de la escisión de agrupaciones ya existentes. Al fracturarse el JAEN en 1970, surgió la Fuerza para la Organización Revolucionaria Peronista (FORPE), la cual reunió a buena parte de los estudiantes de Derecho y de Filosofía y Letras que habían formado parte de los frentes universitarios dirigidos por Galimberti (Larraquy y Caballero, 2011: 115-116). En suma, el fin de una década y el comienzo de otra, dejó en el tintero la desaparición de la CGTA y un variopinto de siglas en el peronismo universitario.

\section{Docentes e intelectuales en las Cátedras Nacionales}

Como venimos describiendo, los años posteriores a 1966 trajeron cambios en la situación del peronismo en la UBA. Sin embargo, sería un error reducir todo este proceso al movimiento estudiantil. A fines de los sesenta, surgieron las Cátedras Nacionales $(\mathrm{CN})$ en la carrera de Sociología de la Facultad de Filosofía y Letras, una experiencia inesperada que involucró a docentes, intelectuales, jóvenes graduados y estudiantes avanzados. Lo primero a tener en cuenta es que las $\mathrm{CN}$ no fueron un proyecto colectivo planificado de antemano. La denominación surgió espontáneamente de una parte del alumnado que se sintió interpelado por un reducido número de materias, seminarios y actividades extracurriculares que explicitaban su adhesión al peronismo ${ }^{62}$.

La aparición de las CN nos retrotrae a la intervención universitaria decretada por Onganía el 29 de julio de 1966, ya que están vinculadas al éxodo de profesores que se desató tras "La noche de los bastones largos". En la actualidad, algunos trabajos han señalado que es inadecuado sobredimensionar ese proceso y hablar de una "ola masiva de renuncias" en señal de protesta contra la dictadura. No sólo porque el resto de las universidades vivenciaron otros sucesos, sino porque en la misma institución porteña las reacciones fueron diversas (Suasnábar, 2004: 65-66; Buchbinder, 2010: $191)^{63}$. Sin embargo, en Filosofía y Letras fue amplia la deserción e incluso existieron

buscaba crear un contrapeso a la figura de Vandor. Su principal dirigente fue Gustavo Rearte, acompañado por sindicalistas como De Luca, Benito Romano, Juan Jonsch y Atilio Santillán. El MRP había logrado cierto predicamento en el ciclo de ocupaciones fabriles del Plan de Lucha de la CGT en 1964, donde sus militantes exaltaban las "tomas" porque veían en ellas "posibilidades insurreccionales" para impulsar el regreso de Perón a la Argentina. Según el MRP, el peronismo no tenía que institucionalizarse en un partido, sino impulsar un proceso de liberación nacional y social conducido por la clase obrera. A la agrupación de Rearte se la considera como uno de los núcleos fundacionales del peronismo revolucionario. No obstante, debe notarse que, por entonces, también funcionaba Acción Revolucionaria Peronista, el grupo fundado por Cooke a su vuelta de Cuba en 1963 (Tortti, 2009: 364-365; Bozza, 2014: 72).

${ }^{62}$ Sobre esta cuestión puede consultarse Moscona (2010: 21) y Ghilini y Dip (2015). Por otra parte, todos los testimonios orales de integrantes de las $\mathrm{CN}$ que iremos citando a lo largo del apartado coinciden en señalar que el nombre surgió de los mismos estudiantes.

${ }^{63}$ Suasnábar sostiene que la coyuntura de 1966 está demasiado asociada a los hechos acaecidos en la UBA. La generalización de esta representación llevó al oscurecimiento de procesos particulares desarrollados en el resto de las universidades nacionales; pero, más importante aún, fue que acentuó una imagen de ruptura total de un hecho político que, sin minimizar su trascendencia, tuvo diferentes impactos en cada institución académica del país. Esta consideración debe ser tenida en cuenta al interior de la UBA, debido a que no todas las casas de estudio porteñas experimentaron de la misma manera la intervención de Onganía. 
varios profesores que optaron por continuar en sus cargos pero fueron cesanteados al finalizar el año, como el caso de Miguel Murmis, Eliseo Verón, Silvia Sigal y Manuel Mora y Araujo en el Departamento de Sociología (Rubinich, 2007: 260-261) ${ }^{64}$. Para ocupar estos espacios vacantes y crear un dique de contención al activismo político de la facultad, la intervención promovió el ingreso de profesores de la Universidad Católica Argentina (UCA). De esta manera, en 1967 arribaron dos docentes que ocuparían puestos importantes y serían los pilares de las $\mathrm{CN}$ en los años venideros: Justino O'Farrell y Gonzalo Cárdenas. El primero encabezó materias clave de la carrera de Sociología, como Introducción a la Sociología y Sociología Sistemática; mientras el segundo se hizo cargo de Historia Social Argentina. Sin embargo, ambos no fueron simples profesores, dado que en aquel entonces O'Farrell fue nombrado director del Departamento de Sociología y Cárdenas del Instituto de esa misma carrera.

En un primer momento, el activismo estudiantil de Filosofía y Letras -en su mayoría de izquierda y opositor a la dictadura- rechazó las figuras de O'Farrell y Cárdenas. Sin embargo, al poco tiempo los dos demostraron una amplitud ideológica que los situaba más cerca de corrientes posconciliares en diálogo con el marxismo y otras ideologías, que de un catolicismo cerrado y conservador. Sus trayectorias y antecedentes eran elocuentes al respecto. Cárdenas provenía de la DC, era graduado de economía de la UBA y se especializó en sociología e historia social en la Universidad de Lovaina de Bélgica, donde también había estudiado el cura colombiano Camilo Torres. En la primera mitad de los sesenta, dictaba clases en la Facultad de Ciencias Económicas y se sumó al Centro Argentino de Economía Humana $(\mathrm{CAEH})$, una institución creada en 1963 bajo la influencia de Joseph Lebret. Este sacerdote dominico francés había fundado el Centro Latinoamericano de Economía Humana (CLAEH) en Montevideo y era uno de los principales impulsores del Concilio Vaticano II, con una prédica que reclamaba el compromiso ante la injusticia social y un trabajo teórico que buscaba "desatanizar" al marxismo para sintetizarlo con el pensamiento cristiano (Donatello, 2010: 53-54). En la Argentina, el CAEH era un centro de investigación que realizaba conferencias y publicaciones. Tenía conexiones con el MHR de Filosofía y Letras y la Asociación Sindical Argentina (ASA), que en ese entonces integraba la CGT. Esto le permitió a Cárdenas dictar cursos de capacitación sindical en la central obrera y dirigir la revista Cambio, una publicación que realizaban universitarios del $\mathrm{CAEH}$, donde no sólo habían referencias a Lebret, sino que también se hablaba de la necesidad de crear una "universidad nueva" en una "argentina liberada" 65.

O'Farrell, por su parte, era un sacerdote jesuita que había realizado un posgrado en sociología en los Estados Unidos, con una fuerte orientación funcionalista. En sus viajes a Europa había tomado contacto con el pensamiento católico renovador que irradiaban centros como la Universidad de Lovaina (Zanca, 2006: 192). Junto con Cárdenas, había formado parte del plantel docente que seleccionó José Enrique Miguens para fundar en 1959 la segunda carrera de Sociología del país en la Facultad de Ciencias Sociales

\footnotetext{
${ }^{64}$ Entrevista a Silvia Sigal, La Plata, 29/10/2013.

${ }^{65}$ Pueden encontrarse documentos del CAEH y una reseña de su historia en Mayol, Habegger y Armada (1970: 127-128).
} 
Dip. Antecedentes y orígenes de las primeras experiencias de peronización en la UBA. 1966 - 1970.

y Económicas de la UCA ${ }^{66}$; O'Farrell estuvo a cargo de la materia Cambio Social y Cárdenas de Historia Social Argentina. Esta experiencia terminó abruptamente en 1966 cuando Miguens debió renunciar frente a la presión de los sectores conservadores de la UCA, fortalecidos tras la llegada de Onganía al poder (Suárez, 1973). Uno de los acontecimientos que desencadenó este hecho, fue que Miguens se negó a despedir a un grupo de profesores que se manifestaron contra la injerencia estadounidense en Vietnam. A esto se sumaba que docentes fueron amonestados y estudiantes suspendidos por posicionarse contra la intervención de las universidades estatales. Cuando Miguens se retiró, Cárdenas renunció con la mayor parte del equipo docente del Departamento de Sociología en solidaridad con él. O'Farrell continuó en su cargo, pero fue cesanteado al poco tiempo (Aramburu y Giorgi, 2013; Zanca, 2006: 197-206) ${ }^{67}$.

Como vemos, el mundo católico de donde provenían Cárdenas y O'Farrell era complejo y poco lineal. No obstante, lo que describimos anteriormente no termina de explicar su arribo a cargos docentes y de gestión en Filosofía y Letras. Una hipótesis probable es que en 1967 hayan sido promovidos por sectores vinculados al ministro del Interior Guillermo Borda y al subsecretario de Educación Emilio Mignone. Ambos habían ocupado espacios de gestión durante el primer peronismo y el segundo tenía una larga militancia en el movimiento católico ${ }^{68}$. De todas maneras, si la idea de Borda y sus funcionarios fue incorporar a docentes de la UCA con la intención de desplazar el exceso de politización y todo lo que asociaban a izquierda en la universidad, en el caso de Cárdenas y O'Farrell no tuvieron el resultado esperado. Al poco tiempo de su arribo a Filosofía y Letras, sumaron a sus cátedras y dieron lugar en materias optativas o seminarios extracurriculares a un conjunto de estudiantes avanzados y jóvenes graduados que en muchos casos provenían de una militancia de izquierda. La mayor parte eran de la carrera de Sociología, aunque también había algunos de Filosofía y Antropología.

Un núcleo vinculado a la primera disciplina era el de Roberto Carri, Susana Checa, Alcira Argumedo y Horacio González. En sus primeros años de estudio habían participado en las protestas para que introdujeran autores marxistas en los programas

\footnotetext{
${ }^{66}$ Miguens se graduó de abogado, pero se especializó en Sociología Económica con Talcott Parsons y Pitirim Sorokin en Estados Unidos. Durante los primeros gobiernos de Perón se desempeñó como docente de sociología en la UBA. En 1959, fue convocado por Monseñor Octavio Derisi para organizar y dirigir un Departamento de Sociología en la UCA. Entre los alumnos que pasaron por las aulas de Miguens, podemos nombrar a Atilio Borón, Juan José Llach y Carlos Prego (Aramburu y Giorgi, 2013).

${ }^{67}$ En 1973 el diario La Opinión repasó la trayectoria de O'Farrell de la siguiente manera: "El doctor O'Farrell ha recibido títulos académicos en las universidades de Jordan y Berkeley, de los Estados Unidos, de Lovaina, Bélgica, y Gregoriana, de Roma. Fue profesor de sociología en la UCA de Buenos Aires hasta agosto de 1966. Entonces el rectorado lo separó de su cátedra por haberse pronunciado contra la intervención a las universidades, dictada por el gobierno de Juan Carlos Onganía". Véase: "Nuevos decanos en siete facultades", en La opinión, 31 de mayo 1973.

${ }^{68}$ Entrevista a Jorge Carpio, C.A.B.A., 20/11/2015 y 30/10/2015; entrevista a Susana Checa, C.A.B.A., 22/12/2015. Por su parte, Villanueva también sugiere que Cárdenas tuvo contactos con Jorge Salimei, el primer ministro de Economía de Onganía. Ambos habían sido militantes de DC y eran graduados de la Facultad de Ciencias Económicas de la UBA. Entrevista a Ernesto Villanueva, Florencio Varela, 04/05/2014 y 17/09/2014. En relación a este tema, también pueden consultarse algunas referencias breves en Moscona (2010: 17).
} 
de las materias, como en la recordada huelga contra Metodología de la Investigación Social en $1962^{69}$. En aquel momento la carrera de Sociología seguía encabezada por quien la había fundado en 1957: Gino Germini ${ }^{70}$. El joven Carri había empezado a militar en la segunda mitad de los cincuenta en la FJC. A principios de la década siguiente, se vinculó al Círculo de Estudios Sociales Luis E. Recabarren que editaba la revista El Obrero (Duhalde, 2011: 139). Luego, a mediados de los sesenta, tuvo un paso por el Ministerio de Trabajo y dirigió la revista Estudios Sindicales, donde participaron como editores Rodolfo Ortega Peña y Eduardo Luis Duhalde, por entonces jóvenes abogados laboralistas y asesores legales de la $\mathrm{UOM}^{71}$. Ambos habían hecho sus primeros pasos militantes en espacios no peronistas. Ortega Peña en el PC tras una primera aproximación al radicalismo frondicista y Duhalde en el humanismo. En los tempranos sesenta habían realizado su pasaje al peronismo y mantenido contactos con distintos actores del sindicalismo y la izquierda nacional (Tarcus, 2007: 306). Tras el golpe de Onganía, Carri también integró otro emprendimiento del dúo Peña-Duhalde: el Centro de Cultura Nacional Carlos Guido Spano. Desde ahí organizaron la editorial Sudestada que publicó su primer libro en 1967: Sindicatos y poder en la Argentina. Como si esto fuera poco, luego de ese año Carri se sumó al JAEN. Al mismo Galimberti lo había conocido por frecuentar ambos el estudio jurídico de Ortega Peña y Duhalde (Larraquy y Caballero, 2011: 69).

Por su parte, González, Argumedo y Checa también habían iniciado su militancia política en la UBA desde la izquierda, pero en las filas del TAU. En un apartado anterior señalamos que esta organización estudiantil respondía al MIRA, una fracción del grupo Praxis de Silvio Frondizi que encabezó Torres Molina en 1961, alegando la necesidad de una ideología revolucionaria y nacionalista que comprendiera mejor al peronismo. González, Argumedo y Checa siguieron el itinerario del TAU que derivó en la constitución del FAU, a raíz de su alianza con el LIM de Grabois y Hopen $^{72}$. Luego del golpe del 1966, al menos González integró por un breve tiempo el

\footnotetext{
${ }^{69}$ La cátedra estaba a cargo de la profesora Regina Gibaja, una de las docentes del grupo cercano a Gino Germani. La protesta de los alumnos consistió en no presentarse a rendir exámenes bajo el eslogan: "contra el empirismo abstracto". Según Argumedo, la crítica central era a los planes de estudio que sólo incorporaban textos de "funcionalistas o del empirismo norteamericano" (2015:24).

${ }^{70}$ La carrera de Sociología fue creada en la UBA en 1957, en la UCA dos años más tarde y en la Universidad del Salvador en 1963. Después del golpe militar de 1966, la carrera se inauguró en otras universidades del interior del país. Pero las tres primeras instituciones siguieron siendo dominantes y se repartían el 90 por ciento de los alumnos hacia 1969 (Rubinich, 2007: 252).

${ }^{71}$ Estudios Sindicales tenía una periodicidad quincenal y fue publicada entre octubre de 1966 y febrero de 1967. Carri firmaba con su apellido materno: Cappagli. La misma dio cuenta, entre otros acontecimientos, de la primera huelga general a la dictadura -el 14 de diciembre de 1966- y de las primeras discusiones acerca del posicionamiento frente al gobierno militar. Asimismo, brindó información de distintos conflictos obreros, especialmente de las ramas industriales afectadas por la política de racionalización económica de la dictadura. Además, proporcionaba datos sobre distintas actividades de la CGT (Nassif y Dawyd, 2014).

${ }^{72}$ Entrevista a Alcira Argumedo, C.A.B.A., 01/11/2012; Entrevista a Susana Checa, C.A.B.A., 22/12/2015; "Éramos como hojas en la tormenta" [Entrevista a Horacio González], en Política, cultura y sociedad en los '70, № 10, 1998.
} 
Dip. Antecedentes y orígenes de las primeras experiencias de peronización en la UBA. 1966 - 1970.

FEN, en sus etapas finales como estudiante y primeros pasos como graduado (Trímboli, 1998: 78; Feinmann y González, 2013: 73; Grabois, 2014: 150). Como mostramos, esta agrupación de pasaje al peronismo encabezada por Grabois se había formado en 1967 con varios militantes del FAU, algunos provenientes del LIM y otros del TAU.

Al FEN también se sumaron brevemente otros futuros integrantes de las $\mathrm{CN}$ que estudiaron sociología, pero que no habían realizado los mismos pasos previos que los ya nombrados. Uno era Ernesto Villanueva; por haber cursado un tiempo en la Facultad de Ciencias Economías hizo su ingreso al FEN por la vía de RR, la agrupación estudiantil reformista encabezada por Peola ${ }^{73}$. Otro era Juan Pablo Franco, quien luego de haber participado en actividades del MHR y de un paso fugaz por ANDE, recaló en el FEN. A mediados de los sesenta, también realizó militancia barrial con grupos peronistas en la zona sur del Gran Buenos Aires, junto a Argumedo y otros estudiantes de sociología que serían integrantes de las CN, entre los que estaban Pedro Krotsch y Fernando Álvarez, el hermano mayor de Carlos, el estudiante de historia que en ese tiempo militaba en JAEN y luego integraría FORPE ${ }^{74}$.

Una trayectoria bastante particular vinculada a la carrera de Sociología que recaló en las CN, fue la de Jorge Carpio. En los cincuenta había venido de Perú, su país natal, a terminar la escuela secundaria en La Plata. A fines de esa misma década, inició su militancia política en la FJC y una vez en la facultad integró la Agrupación Reformista de Estudiantes de Medicina (AREM). Además, en ese tiempo estudió paralelamente Filosofía y formó parte de Amauta, una agrupación política de estudiantes peruanos que residían en la Argentina, en la cual había partidarios del APRA Rebelde y del $\mathrm{PC}^{75}$. Desde esa organización entabló relaciones con sectores sindicales platenses relacionados a Cooke y al peronismo revolucionario. Por estos contactos, Carpio ingresó a Acción Revolucionaria Peronista (ARP) y en paralelo intentó sumarse a la fallida incursión guerrillera del Ejército Nacional de Liberación de Perú en $1965^{76}$. De vuelta al país, participó en la conformación de la Federación Universitaria para la Revolución Nacional (FURN) hasta irse a estudiar sociología a la capital porteña, carrera que pudo terminar rápidamente por habérsele reconocido equivalencias en sus estudios de filosofía previos ${ }^{77}$.

\footnotetext{
${ }^{73}$ Entrevista a Ernesto Villanueva, Florencio Varela, 04/05/2014 y 17/09/2014; "La transición permanente" [Entrevista a Ernesto Villanueva], en Política, cultura y sociedad en los '70, № 10, 1998.

${ }^{74}$ Entrevista a Juan Pablo Franco, C.A.B.A., 18/10/2016.

${ }^{75}$ El APRA Rebelde era un desprendimiento de la Alianza Popular Revolucionaria Americana (APRA) de Raúl Haya de la Torre. Esta facción fue liderada por Luis De la Puente Uceda y cerca de mediados de los sesenta pasó a llamarse Movimiento de Izquierda Revolucionaria. Por sus vínculos con Cuba, De la Puente Uceda entabló contactos con Cooke (Tortti, 2009: 348-349). Pueden encontrarse referencias a Amauta en Amato y Boyanovsky (2009:40).

${ }^{76}$ ARP fue fundada por Cooke en 1963 luego de su viaje a Cuba, con la intención de generar una organización de cuadros que sea capaz de orientar al movimiento peronista hacia estrategias insurreccionales y armadas. En su estancia en la isla, Cooke también entabló contactos con otros militantes latinoamericanos, los cuales impulsaron focos guerrilleros en sus respectivos países para acompañar la estrategia continental del "Che" en América Latina (Cersósimo, 2008: 193).

${ }^{77}$ Entrevista a Jorge Carpio, C.A.B.A., 20/11/2015 y 30/10/2015.
} 
Entre quienes se incorporaron a las CN había un conjunto de sociólogos que eran "peronistas de primera hora". Por procedencia familiar, como el caso de Ricardo Sidicaro, o por haber comenzado a militar desde un inicio en organizaciones estudiantiles de ese signo político, como Lelio Mármola en la JUP y Enrique Pecoraro y Néstor Momeño en FANDEP ${ }^{78}$. Por otra parte, resulta relevante considerar a quienes ingresaron a las CN pero proviniendo de otras carreras, como Norberto Wilner, Gunnar Olsson, Amelia Podetti y Guillermo Gutiérrez. Los tres primeros eran de Filosofía. Wilner había sido uno de los líderes del TAU junto a Juan Samaja. A esta agrupación también ingresó Olsson aunque de manera mucho más periférica a como lo había hecho Wilner. Amelia Podetti, por su parte, en la segunda mitad de los cincuenta se había licenciado en Filosofía y afiliado al Partido Justicialista (PJ). Llegó a las CN con una gran formación por haber profundizado sus estudios a principios de los sesenta en la Universidad de París y en el Institut Catholique de Francia (Denaday, 2013). Finalmente, Gutiérrez era graduado de Antropología. En su tiempo de estudiante había adherido a ANDE, luego de unos orígenes militantes vinculados a la izquierda ${ }^{79}$.

Las trayectorias descriptas no deben hacer pensar que las $\mathrm{CN}$ fueron un colectivo constituido de antemano al que fueron integrándose distintos actores. Al contrario, toda esta experiencia se desarrolló paulatinamente y comenzó a materializarse a fines de los sesenta. Los que jugaron un papel central en ella fueron O'Farrell y Cárdenas porque desde el Departamento de Sociología permitieron posicionarse como docentes y ayudantes a un conjunto de personas que en su mayoría eran jóvenes graduados. En un primer momento, los agruparon en cada una de sus cátedras. Así, de la mano de O'Farrell se pudieron vincular Carri, Wilner, Olsson, Carpio, Checa, Argumedo, González y Sidicaro al espacio de Sociología Sistemática y a las optativas afines tituladas Problemas de Sistemática. Mientras que, por otra parte, Villanueva, Franco y Álvarez integraron el área de Cárdenas, la cual estaba compuesta por Historia Social Argentina y optativas como Problemas Socioeconómicos Argentinos y Sociología de América Latina. Luego de los primeros acercamientos, se fueron ampliando estos espacios con otros ayudantes, docentes, cátedras y seminarios extracurriculares ${ }^{80}$. Lo que terminó de gestar un ámbito donde convergieron trayectorias vinculadas a la izquierda, el peronismo y el catolicismo.

Todo este recorrido deja sin responder una pregunta relevante ¿cómo eran las lecturas de las $\mathrm{CN}$ sobre las ciencias sociales, la sociología y la historia para poder articular itinerarios diversos y permitir que los propios estudiantes las nominaran

\footnotetext{
${ }^{78}$ Entrevista a Lelio Mármola realizada por Aritz Recalde, C.A.B.A., 23/06/2006.

${ }^{79}$ Entrevista virtual a Guillermo Gutiérrez, 29/11/2016. También véase Gutiérrez (2009: 11).

${ }^{80}$ Pueden consultarse los siguientes programas de las CN: Programa $\mathrm{N}^{\circ}$ 109, Conflicto Social, UBA, FFyL, primer cuatrimestre 1968; Programa $\mathrm{N}^{\circ}$ 112, Problemas socioeconómicos argentinos I, UBA, FFyL, primer cuatrimestre 1968; Programa No 113, Problemas socioeconómicos de América Latina, UBA, FFyL, primer cuatrimestre1968; Programa No 115, Sociología Sistemática, UBA, FFyL, primer cuatrimestre 1968; Programa $\mathrm{N}^{\circ}$ 116, Problemas socioeconómicos argentinos II, UBA, FFyL, segundo cuatrimestre 1968; Programa No 117, Sociología de América Latina, UBA, FFyL, segundo cuatrimestre 1968; Programa No 68, Problemas de Sistemática, UBA, FFyL, primer cuatrimestre 1969; Programa $\mathrm{N}^{\mathrm{o}}$ 153, Nación y Estado, UBA, FFyL, primer cuatrimestre 1971. Todas las optativas de las CN eran presentadas en los planes de estudio como "Sociologías Especiales".
} 
Dip. Antecedentes y orígenes de las primeras experiencias de peronización en la UBA. 1966 - 1970.

"Cátedras Nacionales"? Una buena forma de abordar este interrogante es considerando tres libros que fueron publicados en los primeros momentos de la experiencia: 1)- Isidro Velázquez. Formas prerrevolucionarias de la violencia; 2)- Ser social y Tercer Mundo (Elementos para una lógica de lo nacional); y 3)- Las luchas nacionales contra la dependencia. El primero data de 1968 y fue el segundo libro de Carri, publicado bajo el sello Sudestada de Ortega Peña y Duhalde ${ }^{81}$. El siguiente trabajo lo editó Galerna en 1969. Era la tesis de licenciatura en filosofía de Wilner ${ }^{82}$. El tercero, también publicado por esa misma editorial en 1969, era un extenso escrito de Cárdenas para su cátedra de Historia Social Argentina ${ }^{83}$.

Nombramos estas obras porque más allá de sus particularidades, en ellas se expresa claramente el discurso político-intelectual que tejieron las $\mathrm{CN}$ para legitimar su existencia y sus intervenciones. El mismo consistía en cuatro grandes tópicos relacionados entre sí: 1)- Reducía la trayectoria anterior de la carrera de sociología a una disputa entre herederos del funcionalismo estadounidense y de la izquierda tradicional. 2)- Señalaba que ambas corrientes eran incapaces de comprender la situación particular de Argentina y América Latina, porque partían de una visión eurocéntrica que era deudora de la vieja dicotomía sarmientina de civilización o barbarie; como lo demostraban el esquema funcionalista de pasaje de la sociedad tradicional a la moderna y las teorías marxistas que sólo abordaban el conflicto social desde la contradicción burguesía-proletariado. 3)Consideraba al propio trabajo de las $\mathrm{CN}$ como pionero de un nuevo enfoque "nacional" y "tercermundista" en el ámbito de la sociología y las ciencias sociales argentinas, debido a que no pasaba por alto la oposición fundamental entre imperialismo-nación 4)Afirmaba a partir de esta perspectiva que el movimiento de liberación nacional y social propio de la Argentina era el peronismo.

Desde ya que estas posturas no hacían justicia con el breve pero intenso desarrollo que había tenido la carrera de Sociología en Filosofía y Letras. Tampoco era una novedad de las $\mathrm{CN}$ la introducción de la cuestión nacional, la dependencia y el tercer mundo. Este planteo de una u otra forma podía encontrarse en distintos intelectuales

\footnotetext{
${ }^{81}$ En este trabajo, Carri traza las primeras pinceladas críticas referidas al rol del sociólogo. La historia de este peón rural que sufrió el hostigamiento policial y fue acusado de producir hechos delictivos, le suministra material para pensar las "formas violentas de protesta que no adoptan manifiestamente un contenido político pero que indudablemente lo tienen". Retomando a Sarmiento y a Frantz Fanon, Carri se opone a calificar a Velázquez como "bandolero social", una categoría utilizada por Eric Hobsbawn para indicar formas "primitivas" de protesta social en las sociedades campesinas europeas. Para el autor, si los sociólogos utilizan acríticamente conceptos exportados, pueden perder de vista experiencias de lucha política que "forman parte de la cultura autónoma de un pueblo". (Carri, 2011; Nahmías, 2015: 43-45).

${ }^{82}$ Este libro involucró a otros dos integrantes de las CN: al director de tesis, O'Farrell, y a Podetti, la prologuista. En este trabajo, Wilner retoma el concepto de "ser social" que propone Karl Marx en el "Prólogo de la Contribución a la Crítica de la Economía Política", para indagar si es posible pensar a través suyo la lógica del "ser nacional" (Wilner, 1969: 43).

${ }^{83}$ En este libro, Cárdenas se propone el abordaje de una "historia social argentina" desde un "nuevo enfoque sociológico" que vincula el examen de las clases sociales y los movimientos nacionales. De esta manera, recurre a un sinfín de trabajos que van desde Germani, Fanon, Fernando Cardoso, Peter Worsley, Andrew Gunther Frank, hasta Milcíades Peña, José Carlos Mariátegui y José Luis Romero (Cardenas, 1969).
} 
vinculados a la izquierda y el peronismo ${ }^{84}$. Sin embargo, la experiencia que encabezaron Cárdenas y O'Farrell brindó un espacio concreto a estudiantes y jóvenes graduados que por sus propios itinerarios previos estaban ávidos de escuchar esos tópicos discursivos y por definir su pasaje al peronismo. Si la CGTA ofreció una opción concreta en el ámbito político para tramitar ese tránsito, las $\mathrm{CN}$ lo hicieron en el plano mismo de la academia y la discusión intelectual. Pese a que presentamos esquemáticamente sus posiciones, el estudio socio-histórico de Cárdenas, la puesta en primer plano de la figura de Isidro Velázquez por Carri y el análisis del concepto de ser social en la obra de Marx realizado por Wilner, eran trabajos argumentados que incluían una extensa batería de citas y conceptos teóricos. Por esta razón, fueron herramientas largamente aprovechadas por la militancia estudiantil peronista o en tránsito de peronización.

\section{Ser universitario peronista en los sesenta}

Como argumentamos a lo largo del artículo, la situación del peronismo en la UBA comenzó a modificarse luego del golpe de 1966. Lentamente surgieron nuevos agrupamientos universitarios que adhirieron o mostraron amplias simpatías por ese movimiento. La mayoría de sus fundadores eligieron la palabra "nacional" para nombrar a estos espacios o en algunos casos optaron por identificarse directamente como "peronistas". En retrospectiva, es necesario preguntarse por el significado de esta experiencia. Varios relatos de la época e investigaciones actuales señalan que la intervención de Onganía fue un antes y después, dado que a partir de ahí fue desplegándose una creciente peronización de estudiantes, docentes e intelectuales ${ }^{85}$. Un buen punto de partida es poner en cuestión esta afirmación general, para abordar las particularidades del panorama porteño. Lo primero que se desprende del análisis que realizamos entre 1966 y 1970 es que no debe exagerarse la idea de "parte aguas" en relación a la intervención de Onganía. Varios de los universitarios que formaron parte de las nuevas agrupaciones provenían de sectores reformistas y católicos que habían abandonado sus posturas antiperonistas antes del golpe e incluso acompañaron activamente a la CGT en su Plan de Lucha de 1964.

\footnotetext{
${ }^{84}$ Estas lecturas de los jóvenes intelectuales peronistas que concebían al movimiento como una vía para encarar la liberación nacional y la revolución social eran en buena medida deudoras de la producción intelectual de Juan José Hernández Arregui, John William Cooke y Rodolfo Puiggrós. El último caracterizaba a este tipo de enfoques como "nacionalismos populares revolucionarios" (1973: 187-194). Los trabajos actuales difieren en la manera de catalogar a estos referentes político-intelectuales. Mientras Georgieff sitúa a Puiggrós y Hernández Arregui dentro de la tradición de la izquierda nacional (2008: 80 y 89); Acha sostiene que Cooke y Hernández Arregui fundaron una visión y una historiografía propia de la izquierda peronista, la cual se distinguía tajantemente de la izquierda nacional (2009: 307). Más allá de las clasificaciones, en sus análisis todos mixturaban el marxismo, el nacionalismo y el peronismo.

${ }^{85}$ Entre los estudios que sostienen ese tipo de lecturas, pueden nombrarse los de Barletta (2001); Reta (2010) y Recalde (2016). Aunque ellos no agotan la lista y son señalados a modo de ejemplo. La idea de tomar a 1966 como un "parte aguas" cruza a distintos trabajos sobre la universidad, los intelectuales y el movimiento estudiantil. En relación a esta cuestión, puede consultarse la introducción al presente dossier (Dip, 2017) o el amplio estado de la cuestión sobre peronización que realizamos en la tesis doctoral (Dip, 2017).
} 
Dip. Antecedentes y orígenes de las primeras experiencias de peronización en la UBA. 1966 - 1970.

Otro tema importante es no sobredimensionar la peronización y tampoco abordarla como un proceso ineluctable. El surgimiento de grupos como el FEN, UNE, CENAP, JAEN, CEP y las CN si bien cambió la situación del peronismo en relación a los viejos tiempos de la CGU y la JUP, estuvo lejos de convertirlo en hegemónico en la UBA. A decir verdad, a fines de los sesenta sus organizaciones estudiantiles estaban fuertemente fragmentadas y las CN eran una experiencia anclada en Filosofía y Letras. Ellas mismas afirmaban esto en un documento que difundieron en diciembre de 1969, donde reconocían que eran una minoría en la facultad y hasta en la propia carrera de Sociología ${ }^{86}$. De todos los grupos que nombramos, el que más peso y visibilidad tuvo en ese momento fue el FEN, aunque no logró articular detrás de sí al resto de siglas del peronismo universitario. El espacio que terminó cumpliendo esa función de enlace fue la CGTA que encabezó Ongaro, la cual coordinó varias acciones conjuntas con estos grupos y la FUA, a medida que crecía el frente opositor a la dictadura en 1968 y, sobre todo, al año siguiente con el Cordobazo y otros levantamientos populares en el interior del país. Pero más allá de esta cuestión, en el caso particular de la UBA no sería adecuado caracterizar a la peronización de esos años como un proceso de adhesión masiva de estudiantes, docentes e intelectuales al peronismo.

A esta problemática también se suma lo inadecuado de describir el pasaje al peronismo en términos generales y sin aclarar su orientación. La nacionalización y la peronización de los núcleos universitarios que abordamos eran bien específicas. Ellos no pedían volver a los primeros gobiernos peronistas, ni crear la comunidad organizada. $\mathrm{Su}$ idea de ser nacionales y de ser peronistas estaba íntimamente ligada a ser antiimperialistas y socialistas. El ideario de un nacionalismo revolucionario anclado en el concepto de liberación no era nuevo. Antes de 1966 existían expresiones universitarias donde estos enfoques eran recurrentes. Pero lo particular de los grupos como el FEN, UNE, JAEN, CENAP y otros, era que tramitaron esa nacionalización mediante su peronización. A su entender, el peronismo era la única opción política que podía concretar esos horizontes tercermundistas y revolucionarios. En este punto, fueron importantes las producciones de las CN porque generaron nuevos aportes político-intelectuales para argumentar estas posiciones. No obstante, la que jugó un papel clave fue la CGTA porque les ofreció un espacio concreto para converger con sectores de la clase obrera en la oposición a la dictadura, desde un programa que mixturaba peronismo, cristianismo posconciliar y medidas con tintes anticapitalistas ${ }^{87}$.

En este artículo, intentamos dejar de lado los recorridos lineales e ineluctables con la finalidad de analizar estilos concretos de peronización, los cuales pueden reconstruirse acudiendo a una diversidad de trayectos, discursos y coyunturas político-académicas. Sintomático de este asunto no es sólo el surgimiento de las agrupaciones que analizamos

\footnotetext{
86 "Sociología: Instrumento de conocimiento y de lucha", diciembre 1969. Reproducido en Cristianismo y Revolución, $\mathrm{N}^{\circ}$ 22, enero 1970.

${ }^{87}$ Cavarozzi reconoce que más allá de la desaparición de la CGTA, su discurso de oposición frontal al régimen de Onganía fue acentuando los contenidos anticapitalistas y proporcionó material ideológico como "práctico", disponible para ser apropiado por otros protagonistas en acciones colectivas de distinta índole (1983: 42).
} 
en los apartados precedentes, sino también sus desarrollos posteriores. Justamente el FEN, el grupo más importante de pasaje al peronismo a fines de los sesenta, no fue el protagonista central de la nueva etapa abierta entre 1972 y 1973 que culminó con el retorno del peronismo al poder. En esos años, terminaría abandonando progresivamente el discurso sobre el socialismo nacional y distanciándose de los militantes provenientes de UNE, JAEN, CENAP, CEP, FANDEP y las CN que protagonizarían la constitución de la Juventud Universitaria Peronista (JUP) y la Agrupación Docente Universitaria Peronista (ADUP), bajo la hegemonía de Montoneros y la JP Regionales. Si bien esta cuestión no es el tema del presente trabajo, no deja de ser sugestiva a la hora de reafirmar la necesidad de dejar de concebir de manera abstracta y general las experiencias de politización de la historia reciente argentina.

\section{Referencias bibliográficas}

Acha, O. 2009. Historia Critica de la historiografia argentina. Vol. 1: las izquierdas en el siglo $X X$, Bs.As., Prometeo.

Acha, O. 2011. Los muchachos peronistas. Orígenes olvidados de la Juventud Peronista (1945-1955), Bs. As., Planeta.

Amato, F. y Boyanovsky, B. 2009. Setentistas. De La Plata a la Rosada, Bs. As., Sudamericana.

Aramburu, L. y Giorgi, G. 2013. "Recuperando trayectorias olvidadas: José Enrique Miguens, sociólogo". En Primer Congreso de Sociólogos de la Provincia de Buenos Aires.

Argumedo, A. 2015. "Roberto Carri”. En: Carri, R., Roberto Carri: obras completas, Bs. As., Biblioteca Nacional, Tomo I.

Bárbaro, J. 2009. Juicio a los '70, Bs. As., Sudamericana.

Bartoletti, J. 2010. Montoneros: de la movilización a la organización. Un caso paradigmático de militarización, Tesis Doctoral, UNSAM.

Barletta, A. M. 2001. "Peronización de los universitarios (1966-1973). Elementos para rastrear la constitución de una política universitaria peronista", en Pensamiento Universitario, $\mathrm{N}^{\circ} 9$.

Baschetti, R. 2007. La memoria de los de abajo 1945-2007, La Plata, De la Campana, Tomo I.

Baschetti, R. 2016. Peronistas que estudian. De los libros de lectura a la lectura de la realidad, Bs.As., Jirones de mi vida.

Bozza, A. 2014. "La resignificación revolucionaria del peronismo y sus protagonistas durante la etapa de proscripción”. En Tortti, M. C. (dir.). La nueva izquierda argentina (1955-1976): socialismo, peronismo y revolución, Rosario, Prohistoria Ediciones.

Buchbinder, P. 1997. Historia de la Facultad de Filosofía y Letras, Bs. As., Eudeba. Buchbinder, P. 2010. Historia de las universidades argentinas, Bs. As., Sudamericana.

Califa, J. S. 2014. Reforma y revolución. La radicalización política del movimiento estudiantil de la UBA 1943-1966, CABA, Eudeba. 
Dip. Antecedentes y orígenes de las primeras experiencias de peronización en la UBA. 1966 - 1970.

Cárdenas, G. 1969. Las luchas nacionales contra la dependencia, Bs.As., Galerna.

Carri, R. 2011. Isidro Velázquez. Formas prerrevolucionarias de la violencia, Bs.As., Colihue.

Castro, F. y Salas, E. 2011. Norberto Habegger. Cristiano, descamisado, montonero, Bs. As., Colihue.

Cavarozzi, M. 1983. Autoritarismo y Democracia, Bs. As., CEAL.

Ceballos, C. A. 1985. Los estudiantes universitarios y la política (1955-1970), Bs. As., Centro Editor de América Latina, 1985.

Cersósimo, F. 2008. Envar El Kadri. Historias del peronismo revolucionario, Bs.As., Colihue.

Corvaglia, R. 2016. "La militancia al servicio de la causa nacional y popular en los claustros universitarios", en Baschetti, R. Peronistas que estudian. De los libros de lectura a la lectura de la realidad, Bs.As., Jirones de mi vida.

Denaday, J. P. 2016. “Comando de Organización: un peronismo plebeyo, combativo y nacionalista (1961-1976)". En: Quinto sol, Santa Rosa, N 1.

Denaday, J.P. 2013. "Amelia Podetti: una trayectoria olvidada de las Cátedras Nacionales". En: Nuevo Mundo Mundos Nuevos.

Deschner, K. 2004. La politica de los Papas en el siglo XX, Zaragoza, Editorial Yalde.

Dip, N. 2017. Libros y alpargatas. Las tramas discursivas y organizativas del proceso de peronización de estudiantes, docentes e intelectuales de la Universidad de Buenos Aires 1966-1974, FaHCE, UNLP, Tesis de Doctorado.

Donatello, L.M. 2010. Catolicismo y Montoneros, Bs.As., Manantial.

Duhalde, E. L. 2011. “Apropósito de Carri y de su obra”. En: Carri, R., Isidro Velázquez, Bs.As., Colihue.

Eggers Brass, T. 2012. "Conrado Eggers Lan, entre la filosofía antigua y el pensamiento nacional”. En Revista de Historia Bonaerense, №39.

Feinmann, J.P., y González, H. 2013. Historia y pasión, Bs. As., Planeta

Georgieff, G. 2008. Nación y revolución. Itinerarios de una controversia en Argentina (1960-1970), Bs.As., Prometeo, 2008.

Ghilini, A. y Dip, N. 2015. "Experiencias de peronización en la Universidad de Buenos Aires entre la dictadura de Onganía y el gobierno de Cámpora". En: Revista Izquierdas, $\mathrm{N}^{\mathrm{o}} 25$.

Gilbert, I. 2009. La Fede. Alistándose para la revolución. La Federación Juvenil Comunista 1921-2005, Bs. As., Sudamericana.

Grabois, R. 2014. Memorias de Roberto Pajarito Grabois: de Alfredo Palacios a Juan Perón (1955-1974), CABA, Corregidor.

Gutiérrez, G. 2009. “Antropología 3er Mundo. Cuatro décadas, algunas reflexiones sobre el contexto de origen”. En Antropología 3er. Mundo, Edición facsimilar FFyL, UBA.

Larraquy, M. y Caballero, R. 2011. Galimberti. De Perón a Susana de Montoneros a la CIA, Bs. As., Aguilar/Altea/ Taurus/Alfaguara, 2011.

Martín, J.P. 2010. El Movimiento de Sacerdotes para el Tercer Mundo. Un debate argentino, Los polvorines, UNGS. 
Mayol, A., Habegger, N., y Armada, A. 1970. Los católicos posconciliares en la Argentina, Bs. As., Galerna.

Morello, G. 2003. Cristianismo y Revolución. Los orígenes intelectuales de la guerrilla argentina, Córdoba, UCC.

Morero, S. 1996. La noche de los bastones largos 30 años después, Bs.As., Documentos Pagina 12.

Moscona, G. 2010. Peronismo e intelectuales. La experiencia de las Cátedras Nacionales en la Universidad de Buenos Aires en el período 1967-1974, Tesis de Maestría, FSOC, UBA.

Nahmías, G. 2015. "Roberto Carri: el pensamiento soslayado. Estudio preliminar". En: Carri, R., Roberto Carri: obras completas, Bs. As., Biblioteca Nacional, Tomo I.

Nassif, S. y Dawyd, D. 2014. "La revista Estudios Sindicales de Roberto Carri. Un documento para el estudio de la clase obrera de los sesenta". En: Corpus, Vol. 4, $\mathrm{N}^{\mathrm{o}} 2$.

Panella, C. 2013. "Actitud: un periódico nacionalista para los estudiantes universitarios peronistas". En: XIV Jornadas Interescuelas/Departamentos de Historia, Facultad de FFyL, UNCUYO.

Puiggrós, R. 1973. “Tesis sobre el Nacionalismo Popular Revolucionario". En: Las Izquierdas y el Problema Nacional, Bs.As., Ediciones Cepe.

Ramus, S. 2007. Sueños sobrevivientes de una montonera a pesar de la ESMA, Bs.As. Colihue.

Recalde, A. 2016. Intelectuales, peronismo y universidad, Bs. As., Punto de Encuentro. Regali, E. A. 2012. Abelardo Ramos. La izquierda nacional y la nación latinoamericana, Córdoba, Ferreyra Editor/Ediciones del Corredor Austral/CICUSS, 2012.

Reta, A. 2010. El proceso de peronización dentro del movimiento universitario en los años sesenta. El caso del FEN, Tesis de Maestría, FSOC, UBA.

Rot, G. 2010. Los orígenes perdidos de la guerrilla en la Argentina: la historia de Jorge Ricardo Masetti y el EGP, Bs. As., Waldhuter.

Rubinich, L. 2007. "La modernización cultural y la irrupción de la sociología". En: James, D. (comp.), Violencia, proscripción y autoritarismo (1944-1976), Bs. As., Sudamericana.

Salas, E. 2014. De resistencia y lucha armada, CABA, Punto de Encuentro.

Sigal, S. 1991. Intelectuales y poder en la década del sesenta, Bs. As., Puntosur.

Sotelo, L. 2012. "El mundo sindical entre la acción gremial y la acción política. Continuidades y rupturas de la CGT de los Argentinos respecto de las experiencias anteriores". En: Tortti, M. C. (coord.) El lugar de la nueva izquierda en la historia reciente, PolHis - Boletín Bibliográfico Electrónico del Programa de Historia Política, $\mathrm{N}^{\mathrm{o}} 10$.

Suárez, F. 1973. "Algunas reflexiones sobre los procesos de institucionalización de la Sociología en la Argentina durante los últimos años", en Revista Mexicana de Sociología, $\mathrm{N}^{\circ} 1$.

Suasnábar, C. 2004. Universidad e intelectuales. Educación y política en la Argentina (1955-1976), Bs. As., Manantial, 2004, p. 65-66; 
Tarcus, H. (dir.) 2007. Diccionario biográfico de la izquierda argentina, Bs. As., Emecé, 2007.

Tortti, M. C. 2009. El viejo partido socialista y los orígenes de la nueva izquierda, Bs. As., Prometeo.

Tortti, M. C. 2013. Che. Una revista de la nueva izquierda (1960-1961), Bs. As., CEDINCI.

Touraine, A. 1969. La sociedad post-industrial, Barcelona, Ariel.

Trímboli, J. 1998. La izquierda en la Argentina, Bs. As., Manantial

Verbitsky, H. 2008. La violencia evangélica. De Lonardi al Cordobazo (1955-1969), Bs. As., Sudamericana.

Wilner, R. 1969. Ser Social y Tercer Mundo (Elementos para una lógica de lo nacional), Bs. As., Galerna.

Zanca, J. 2006. Los intelectuales católicos y el fin de la cristiandad 1955-166, Bs.As., FCE. 